\title{
Treatment of War Wounds
}

\section{A Historical Review}

\author{
M. M. Manring PhD, Alan Hawk, Jason H. Calhoun MD, FACS, \\ Romney C. Andersen MD
}

Received: 16 June 2008/ Accepted: 27 January 2009/Published online: 14 February 2009

(C) The Association of Bone and Joint Surgeons 2009

\begin{abstract}
The treatment of war wounds is an ancient art, constantly refined to reflect improvements in weapons technology, transportation, antiseptic practices, and surgical techniques. Throughout most of the history of warfare, more soldiers died from disease than combat wounds, and misconceptions regarding the best timing and mode of treatment for injuries often resulted in more harm than good. Since the 19 th century, mortality from war wounds steadily decreased
\end{abstract}

Each author certifies that he or she has no commercial associations (eg, consultancies, stock ownership, equity interest, patent/licensing arrangements, etc) that might pose a conflict of interest in connection with the submitted article.

Disclaimer: The opinions or assertions contained herein are the private views of some of the authors and are not to be construed as official or reflecting the views of the Department of Defense or the US government. This work was prepared as part of their official duties and, as such, there is no copyright to be transferred.

M. M. Manring

Department of Orthopaedic Surgery, University

of Missouri-Columbia, Columbia, MO, USA

\section{A. Hawk}

National Museum of Health and Medicine, Armed Forces

Institute of Pathology, Washington, DC, USA

J. H. Calhoun ( $\square)$

Department of Orthopaedic Surgery, The Ohio State University, N1043 Doan Hall, 410 W 10th Ave, Columbus, OH 43210-1228, USA

e-mail: jason.calhoun@osumc.edu

R. C. Andersen

Orthopaedic Traumatology, Walter Reed National Military

Medical Center, Bethesda, MD, USA

R. C. Andersen

Orthopaedic Traumatology, Walter Reed National Military

Medical Center, Washington, DC, USA as surgeons on all sides of conflicts developed systems for rapidly moving the wounded from the battlefield to frontline hospitals where surgical care is delivered. We review the most important trends in US and Western military trauma management over two centuries, including the shift from primary to delayed closure in wound management, refinement of amputation techniques, advances in evacuation philosophy and technology, the development of antiseptic practices, and the use of antibiotics. We also discuss how the lessons of history are reflected in contemporary US practices in Iraq and Afghanistan.

\section{Introduction}

The need for surgical care of survivors of accidents or animal attacks is part of the story of civilization, as is the story of medical care of those wounded in that other peculiarly human endeavor, warfare [41]. During the past 250 years, and particularly during the 20th century, developments in military trauma care for musculoskeletal injuries have greatly influenced civilian emergency medicine. The history of military trauma care must be understood in terms of the wounding power of weapons causing the injury and how the surgeon understood the healing process. Improvements in weapons technology forced surgeons to rethink their interventions in their effort to tip the odds of survival in favor of their patient.

Our purpose is to review the evolution of military trauma care during the past two and a half centuries in major conflicts in the West. The major areas of emphasis are medical evacuation and organization; wounds and wound management; surgical technique and technology, with a particular focus on amputation; infection and antibiotics; and blood transfusion. 


\section{Medical Evacuation and Organization}

Perhaps the most basic problem facing physicians during wartime historically has been whether (and how) to transport the wounded to care or transport the caregivers to the wounded. A secondary problem historically has been how best to organize the delivery of care as modern nations began to dispatch vast armies and navies to fight across vast distances.

For example, Pikoulis et al. [110] reviewed the wounds depicted in The Iliad and determined the arrow wounds such as the one suffered by Menelaus carried a mortality rate of $42 \%$, slingshot wounds $67 \%$, spear wounds $80 \%$, and sword wounds $100 \%$. These high mortality rates suggest surgeons were unable to get to wounded soldiers during the melee, treating only the higher class or those who survived after the battle had concluded. These Greek surgeons, whether they realized it or not, faced the same issues as all future practitioners engaged in wound care: wound management, The Golden Hour (the principle that a victim's chances of survival are greatest if he receives resuscitation within the first hour after a severe injury), and infection control.

During the American Revolution (1775-1783), the Continental Congress authorized one surgeon to serve in each regiment. Few of the regimental surgeons, mostly trained through the apprenticeship system as there were only two medical schools in the United States (King's College [now Columbia University] in New York, NY, and the University of Pennsylvania in Philadelphia, PA), had any experience treating trauma. The organization was minimal, and regimental surgeons tended to work for their unit instead of seeing themselves as part of the Hospital Department, which was rendered ineffective by bureaucratic infighting [116].

The outstanding military surgeon of the Napoleonic Wars (1792-1815), Baron Dominique-Jean Larrey (17661842), generally is regarded as the originator of modern military trauma care and what would become known as triage [131]. He placed surgical teams near the front lines to shorten the time elapsed after injury and instituted specially designed horse-drawn "flying ambulances" in which the wounded rode with an early version of emergency medical technicians $[67,103]$. Care was prioritized to provide first for the most badly wounded, without regard to the patient's chances of survival or the need to restore less gravely wounded soldiers to the front lines quickly [11]. After Larrey's system was used during the Battle of Metz (1793), he was ordered to organize medical care for the entire French Army [131]. Rapid access to care and immediate amputation reduced morbidity and mortality.

The Crimean War (1854-1855) underscored the importance of methods used by Larrey decades earlier, particularly the importance of organized evacuation and surgical care close to the front line. The war revealed a stark contrast between the battlefield care provided by the French, with their expert organization and system of light ambulances, and the poorly organized British Medical Services. Outrage over the poor treatment offered to the British wounded led the War Office to send a young nurse, Florence Nightingale (1820-1910), and a staff of 38 volunteers to the British barracks in Istanbul, Turkey, where Nightingale's first act was to thoroughly scrub the hospital, provide clean bedding, improve ventilation and sewage disposal, and reorganize everyday sanitary procedures. She was an early theorist of sanitation and the design of hospital buildings. Although her efforts created intense resentment in the army bureaucracy, she was one of the founders of the modern nursing profession [48]. She broke the monopoly of health care as the sole providence of the physician, which led to the development of the healthcare team in modern medical practice.

Nikolai Pirogoff (1810-1881), who served in the Imperial Russian Army, brought skilled nurses into military hospitals and worked to modernize Russian medical equipment [133]. He is the namesake for a conservative technique of foot amputation [98].

At the onset of the American Civil War (1861-1865), the US Army and Navy combined had about 100 physicians, many with no experience with battlefield trauma [87], almost 30 of whom resigned to join the Confederacy [45]. The structure of the Medical Department was decentralized with no clear chain of command and control of supplies. The US Army Quartermaster's Corps, whose primary duties were supplying and provisioning troops, were responsible for direct battlefield evacuation. The Regimental Band served as litter bearers. The first Battle of Manassas (July 21, 1861) was a rout for the federal forces and the soldiers fled back to Washington. Ultimately, 2708 men were killed or wounded and the Medical Department could not handle the load. Regimental surgeons, because they worked for their unit only, were either swamped with casualties or idle. Regimental band members and civilian ambulance drivers hired by the quartermaster's corps fled from the battle. Most of the wounded had to walk the 27mile distance from the battlefield to Washington to reach the hospitals in the rear. Those who could not walk remained on the battlefield for several days until they were picked up by ambulances, captured by Confederate forces, or died [62].

The Union Army quickly reorganized its Medical Department in 1862 after prodding by a Sanitary Commission created by President Lincoln [124]. Jonathan Letterman (1824-1872) (Fig. 1) reorganized the medical care in the Army of the Potomac. Wounded soldiers were removed from the battlefield by litter bearer, the 
Fig. 1 Jonathan Letterman, seated at left with members of the medical staff of the Army of the Potomac, organized an efficient medical corps after the disasters of the initial battles of the American Civil War. (Courtesy of the National Library of Medicine, Washington, DC.)

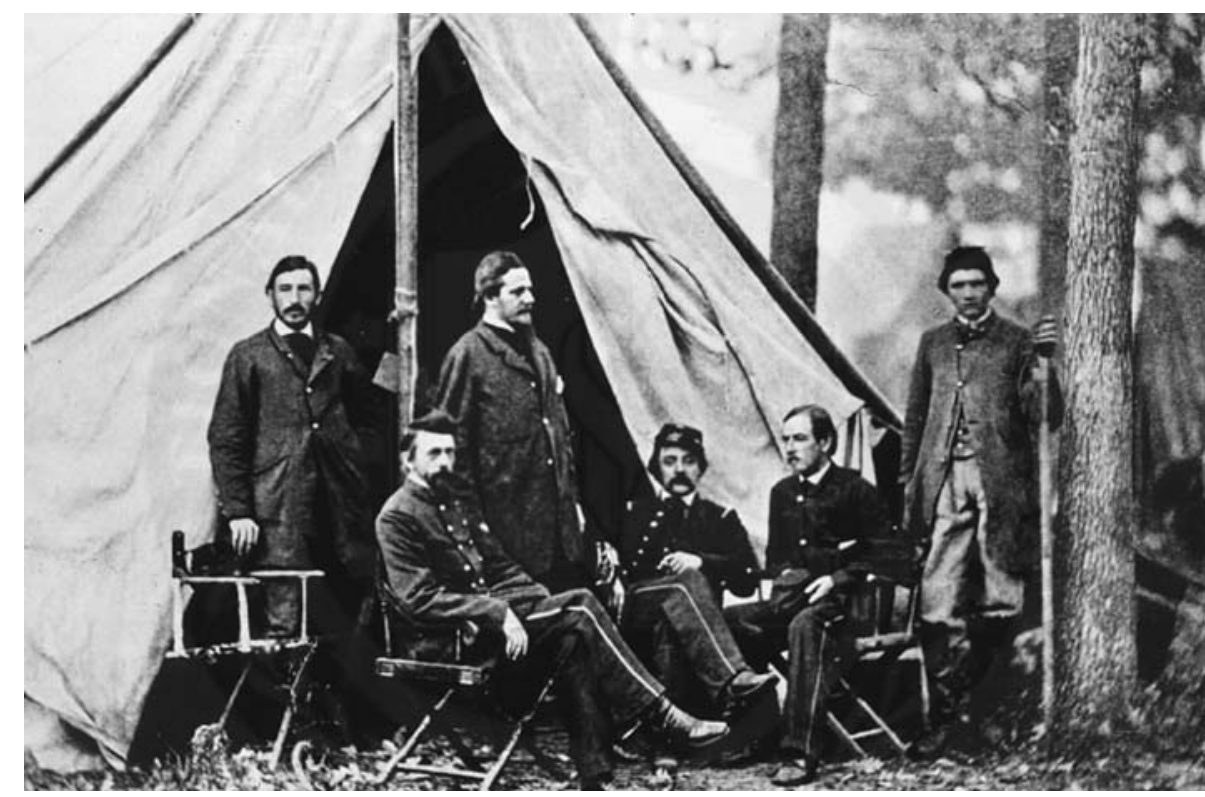

predecessor to the medic or corpsman. Regimental Surgeons were responsible for dressing wounds and patients were evacuated in ambulances driven by Medical Corps noncommissioned officers to a division level field hospital for surgical treatment. By the end of the war, the Medical Department expanded this system by creating a national network of hospital trains, hospital ships, and general hospitals that could treat the patient near his hometown if he so desired [62]. The main advance in American medicine during the Civil War was the creation of an effective military medical corps with medical evacuation, hospitals, and surgical specialists. Health care was beginning to become a system. Still missing was a formalized approach to care that recognized the severity of injuries. The poet Walt Whitman, who worked at several Union hospitals in Washington, DC, noted, "The men, whatever their condition, lie there, and patiently wait until their turn comes to be taken up" [144]. Whitman's poem "The Wound Dresser" (1865) poignantly illustrates the state of care at the time (Appendix 1).

Johann Friedrich August von Esmarch (1823-1908) served as a young surgeon in German campaigns against Denmark in 1848 and 1864 and was appointed surgeon general during the war against France in 1870. His contributions to military medicine were comprehensive, from initial management of wounds, to surgical techniques, to the organizational structure of patient management. In the late 19th century, von Esmarch continued the development of organized trauma care pioneered by Larrey, who as early as 1812 had introduced clear rules for sorting patients: the dangerously wounded would receive first attention, regardless of rank; those with less acute injuries would be treated second. Historically, priority of care for the wounded may have depended on the rank of the injured soldier, an individual surgeon's best guess, the order of arrival, or happenstance. von Esmarch emphasized prioritizing patients by severity of injury but did so to make the most effective use of medical resources, not necessarily to treat the most badly injured first [42]. The familiar concept of triage (from the French "trier", to sort) would be given its name by French physicians in World War I [77], but institution of a rationalized approach to prioritizing care was a decades-long development, from Larrey to von Esmarch to the massive armies of World War I.

The then-unprecedented mass casualties in World War I (1914-1919), with horrific wounds from machine guns and shell fragments, and the effects of poison gas, created terrific strains on British and French medical units. The advent of motorized transport helped make possible the establishment of British Casualty Clearing Stations (CCS) approximately 6 to 9 miles behind the front lines. These were advanced surgical units, staffed by surgeons, anesthetists, and nurses-the closest women had gotten to the front lines in a modern conflict [41]. The stations were designed to admit between 150 and 400 wounded at a time, but they often were overwhelmed with 1000 or more patients. Increasingly, instead of the most badly injured patients being given priority in triage, the time required to provide such treatment compelled British surgeons to prioritize in favor of patients with critical but less complicated wounds [77]. A British manual listed the goals of triage as first conservation of manpower and secondly the interests of the wounded [146].

As US Surgeon General during most of World War II (1939-1945), Norman Kirk (1888-1960) (Fig. 2) oversaw a medical organization more vast than any of his 


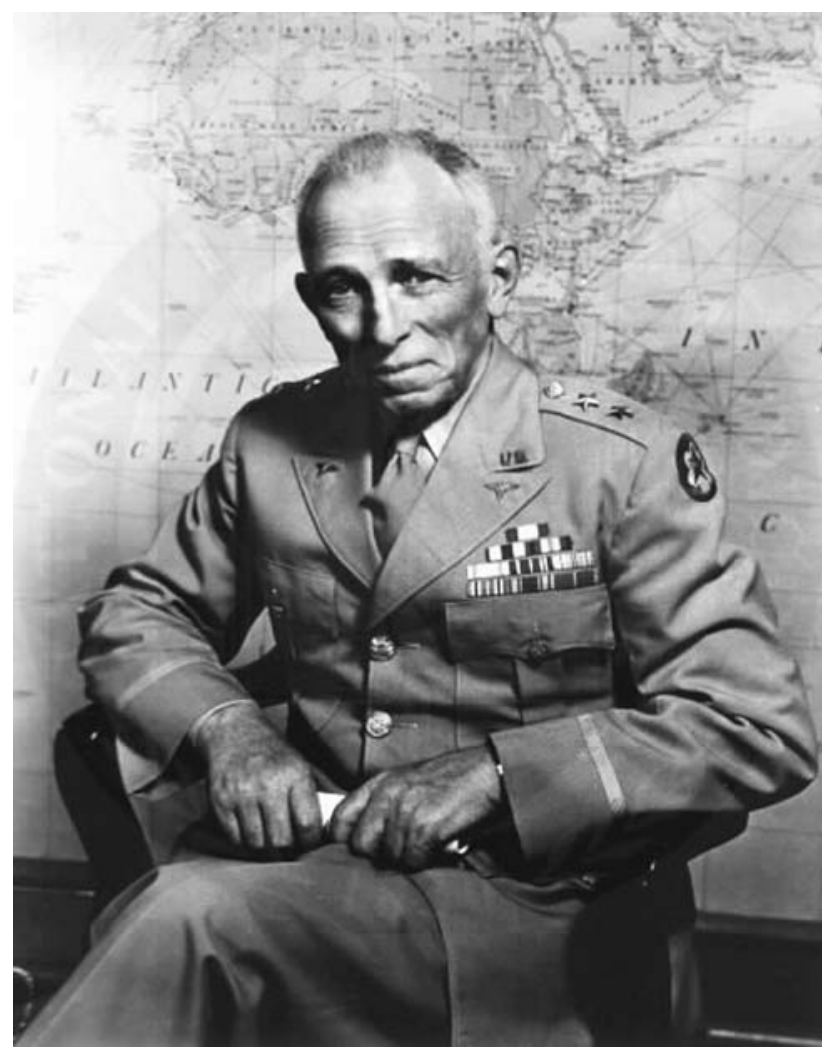

Fig. 2 Norman T. Kirk, the first orthopaedic surgeon to be named US Surgeon General, was responsible for numerous improvements in military trauma care, including guidelines for amputation and an enhanced system of stateside rehabilitation. (Courtesy of the National Library of Medicine, Washington, DC.)

predecessors: 535,000 medics, 57,000 nurses, 47,000 physicians, and 2000 veterinarians. Nearly 700 overseas hospitals were responsible for initial care of the wounded. Stateside, 78 military hospitals cared for nearly 600,000 patients during the war [101]. The chain of care began with combat medics, two of which generally were assigned to each company. They provided initial care and determined whether a wound required evacuation of the patient to a battalion aid station. If additional treatment were required, the patient was evacuated to a divisional clearing station, where the first formal triage of patients occurred and which also served as small surgical hospitals for urgent cases [28]. Definitive care took place at one of the overseas hospitals or a military hospital stateside, in the "Zone of the Interior."

The US Army Medical Department was in the process of reorganizing based on experiences of World War II when the Korean War (1950-1953) began. New Mobile Army Surgical Hospital (MASH) units were developed rapidly under the leadership of the pioneering surgeon Michael DeBakey (1908-1999) to provide resuscitative surgical care within 10 miles of the front lines (Fig. 3). Helicopter ambulance companies supported the MASH, allowing treatment of patients within 3 to 12 hours of wounding [73]. Mortality from all wounds decreased to a low of $2.4 \%$ [39], with mortality from abdominal wounds decreasing to $8.8 \%$ [116].

Improvements in medical evacuation technology and organization, particularly the use of helicopters, again played a major role for US forces in Vietnam (1962-1974). Medics splinted and bandaged the wounded patient, frequently radioing the hospital and warning of his arrival and diagnosis. Helicopter evacuation minimized the use of morphine, eliminating an additional complication. The hospital mortality rate was slightly higher than in Korea, $2.6 \%$, but that increase is probably misleading, as more rapid transport delivered wounded soldiers who would have been listed as killed in action in Korea [99]. Mortality from abdominal wounds declined to 4.5\% [58]. Most soldiers wounded in Vietnam were delivered from the battlefield to fixed hospitals with the capacity to provide definitive treatment, eliminating the need for multiple transfers and levels of care (Fig. 4). Patients not expected to return to full duty within 30 days or less were evacuated to hospitals in Japan and the United States [60].

The nature of combat and improvements in evacuation during the Korean and Vietnam conflicts thus allowed for development of fixed hospitals. Although MASH units continued to provide care, the hospitals grew from 60 beds at the beginning of the Korean War to 200-bed fixed hospitals with metal buildings and concrete floors as the fighting settled into trench warfare by 1952 . By 1990, the weight of all of the equipment for a MASH unit was more than 200,000 pounds, meaning the hospital was mobile in name only. Unlike previous wars, armies of the Persian Gulf War (1990-1991) moved rapidly, and even though several MASH units were staged in trucks, hospitals were unable to keep up with the rapidly advancing front. Although there were few casualties, it was painfully obvious MASH units were too cumbersome to effectively support armored units as they raced into Kuwait and southern Iraq. A new organizational structure was needed [100]. A 20-person Forward Surgical Team (FST) was created to provide resuscitative surgery close to the front lines. The role of the fixed-base hospital was taken by a Combat Support Hospital (CSH), a modular unit capable of supporting between 44 and 248 beds. The reorganization was completed in 2003 when the 212th MASH becoming the 212th CSH while in Iraq [100].

Trauma care for US soldiers in Iraq and Afghanistan currently is provided through five levels of care: Level I, front line first aid; Level II, FST; Level III, CSH, which is similar to civilian trauma centers; Level IV, surgical hospitals outside the combat zone, such as Landstuhl Regional Medical Center, Germany; and Level V, major US military 
Fig. 3A-B (A) The 8208th Mobile Army Surgical Hospital was one of the MASH units created to provide care within a few miles of the front line during the Korean War. (Courtesy of Otis Historical Archives, National Museum of Health and Medicine, Armed Forces Institute of Pathology, Washington, DC.) (B) Mortality from all wounds decreased in Korea owing to more rapid transport via helicopter to operating rooms such as the one staffed by physicians at the 8055th MASH. (Courtesy of Otis Historical Archives, National Museum of Health and Medicine, Armed Forces Institute of Pathology, Washington, DC.)
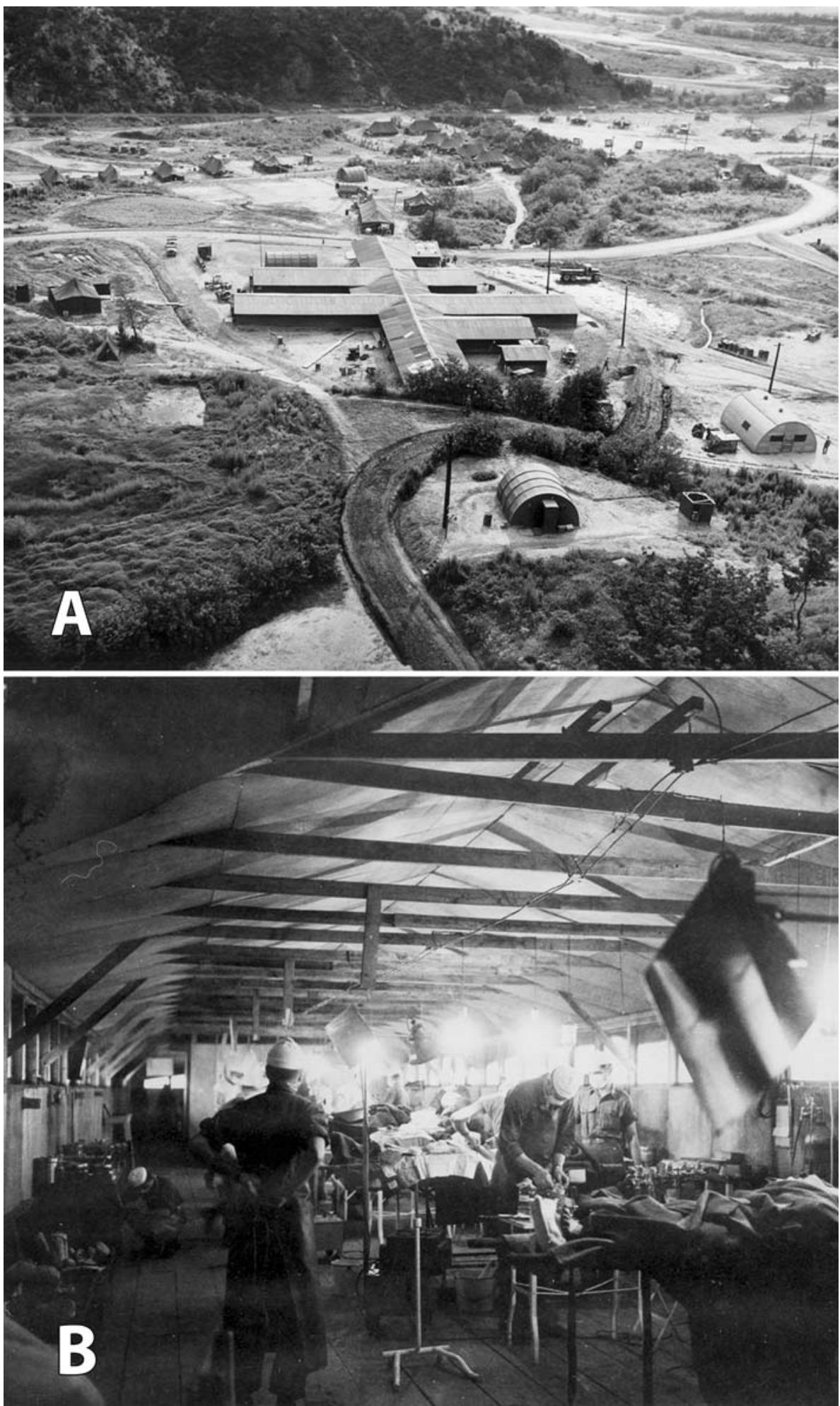

hospitals, such as Walter Reed Army Medical Center in Washington, DC; The National Naval Medical Center in Bethesda, MD; San Diego Naval Medical Center in San Diego, CA; and Brooke Army Medical Center in San Antonio, TX (Table 1) [6]. At the front line, each squad has a combat lifesaver trained in resuscitation, and each soldier is equipped with a tourniquet. If surgical resuscitation is required, the patient is immediately moved to a higher level of care (Fig. 5A). Level III army hospitals are large (248 beds), with surgical specialists, laboratories, radiology, and 


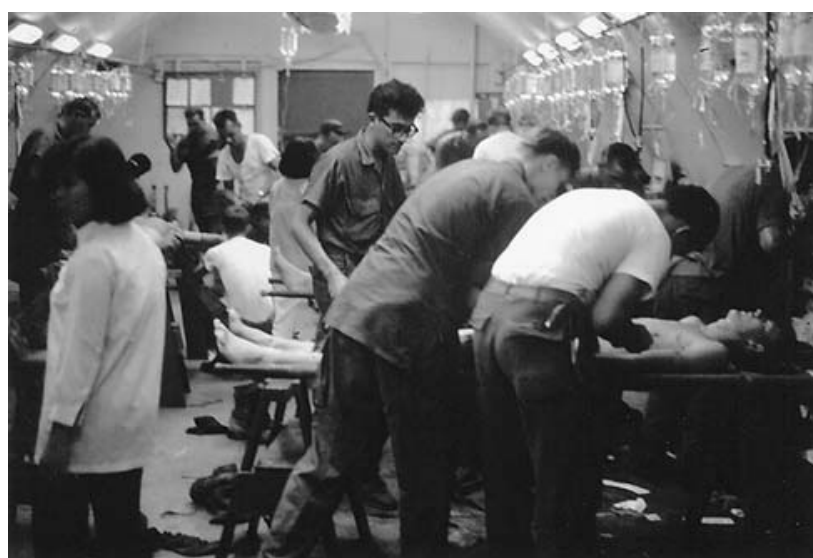

Fig. 4 Casualties arrive at the Naval Support Activity Station Hospital in Da Nang, Vietnam, in 1968. The wounded were transferred from the helicopters to the triage area on canvas-covered stretchers. These were set on sawhorses, where they became examination tables and sometimes operating tables. (From Kelly PJ. Vietnam, 1968-69: a place and year like no other. Neurosurgery. 2003;52:927-943. Reproduced with permission of Wolters Kluwer Health.)

Table 1. Levels of care for US wounded in Iraq/Afghanistan

\begin{tabular}{ll}
\hline Level of care & Description \\
\hline I & $\begin{array}{c}\text { Battalion Aid Station (unit level, combat medic, } \\
\text { immediate first aid and transport) }\end{array}$ \\
II & $\begin{array}{c}\text { Forward Surgical Team, limited emergency surgery } \\
\text { capabilities }\end{array}$ \\
III & Army Combat Support Hospital (theater hospital \\
& with intensive care) \\
IV & Landstuhl Regional Medical Center, Germany \\
& (multidisciplinary surgical trauma management \\
& for catastrophic injury) \\
V & Major stateside trauma centers with teaching \\
& and research: Brooke Army Medical Center, \\
& Walter Reed Army Medical Center, \\
& National Naval Medical Center, \\
& San Diego Naval Medical Center
\end{tabular}

(Modified and reprinted with permission from Nesson SC, Lounsbury, DE, Hetz SP. War Surgery in Afghanistan and Iraq: A Series of Cases, 2003-2007. Washington, DC: Office of the Surgeon General; 2008.)

blood banks. Definitive surgical treatment can be provided first at a Level IV hospital but may be provided at Level V, where limb salvage and reconstructive surgery are performed. All amputees begin rehabilitation at a Level V hospital; burn patients are sent exclusively to Brooke Army Medical Center. The military C-17 transports that have become known as the flying ICUs are capable of bringing the wounded to the United States in as little as 3 days of their wounding, although the actual number of days varies according to the individual patient's requirements (Fig. 5B) [63].

\section{Wounds and Wound Management}

Perhaps the earliest literary account of wound management comes from Homer's epic poem The Iliad (circa 700 BCE), based on events of the Trojan War half a millennium earlier [70]. Combat during this period was chaotic, as opposing formations merged into hand-to-hand combat with edged weapons resulting in heavy casualties. The accounts depict surgeons as skilled and professional physicians who expertly treated wartime trauma. In the fourth book of The Iliad, surgeon Makaon treated King Menelaus of Sparta, who had sustained an arrow wound to the abdomen, by extracting the arrow, sucking blood out of the wound to remove poison [76], and applying a salve [70]. In the eleventh book, Achilles' friend Patroclus extracted an arrow from King Eurypylus of Thessaly, when he "cut out with a knife the bitter, sharp arrow from his thigh, and washed the black blood from it with warm water" [70], which may have been the first record of débridement and soft tissue management (Appendix 2).

One of the longest-enduring rules of wound care, one that would have implications for centuries, came from the works of Hippocrates (460-477 BCE), whose extensive writings included such innovations as chest tubes for drainage, external fixation, and traction to restore proper alignment of fractured bones and important observations about head trauma. Hippocrates believed wounds should be kept dry, only irrigating with clean water or wine, and suppuration in the wound was a part of the healing process as it expelled spoiled blood [116]. This belief in "laudable pus" persisted from at least ancient Greece for more than a millennium. Galen (130-200 CE), author of hundreds of works describing surgical techniques such as trepanning of the skull and treatment of penetrating abdominal wounds, was probably the first to use the Latin term "pus bonum et laudabile" after observing that suppurating wounds were often the first to heal [41]. Although succeeding generations of surgeons who studied wound care had no reason to question the concept of laudable pus, there were a few dissidents, such as the Dominican friar Theodoric (12051296), who asserted, "It is not necessary that pus be formed in wounds" [113]. By the mid-19th century, the formation of pus was considered an inevitable consequence of surgery, but not part of the healing process. Surgery that healed without pus was described as "healing by first intention," and surgeons distinguished between creamy white or yellow laudable pus with the bloody, watery, foulsmelling malignant pus that indicated pyemia often followed by death [15].

Because the physician held higher status than the surgeon during the Middle Ages, few treatises on surgery or wound care were published. One notable exception was Guy De Chauliac (1298-1368), who proposed five 

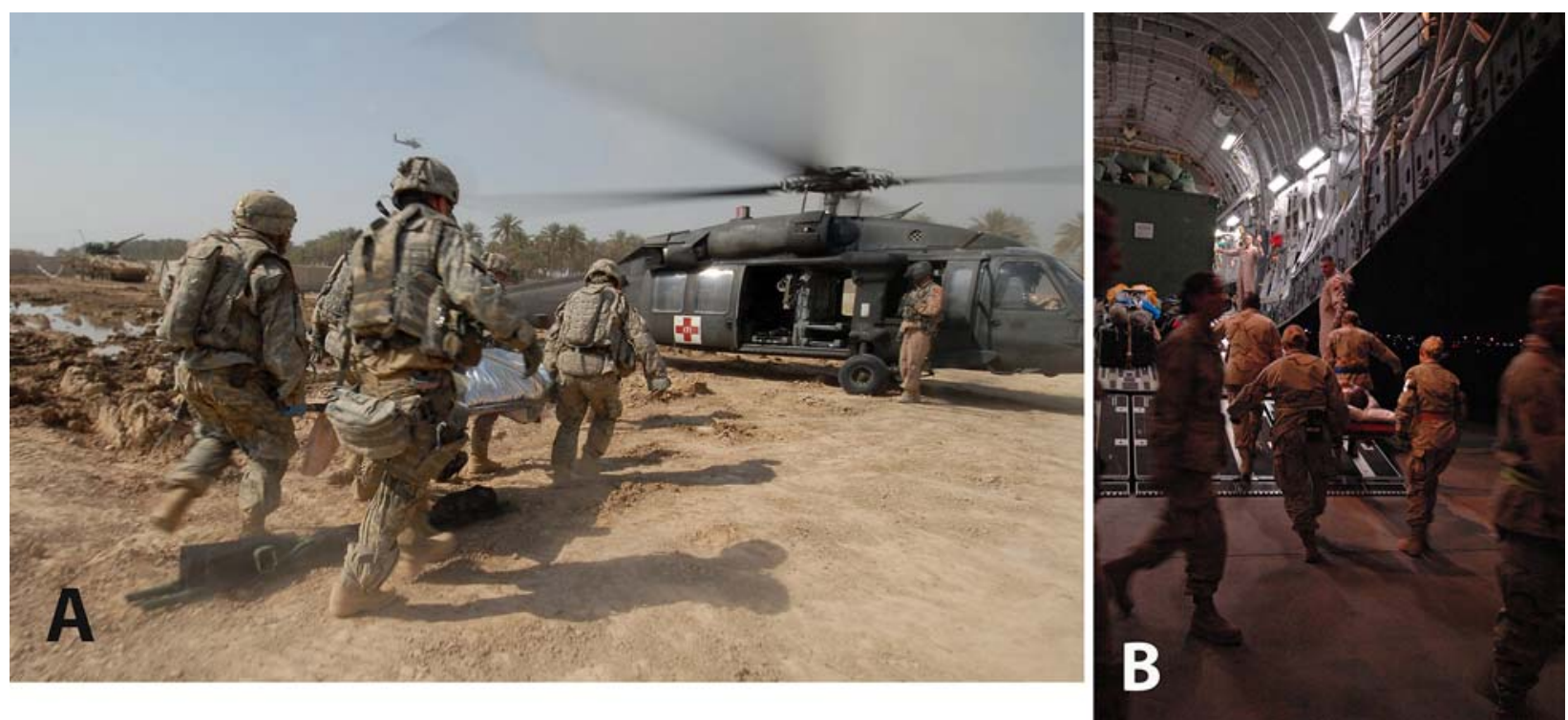

Fig. 5A-B (A) US Army soldiers transport a trauma victim to a US Army medical helicopter in Tarmiyah, Iraq, September 30, 2007. (US Navy photograph by Mass Communication Specialist 2nd Class Summer M. Anderson. Courtesy of the US Department of Defense,

principles for treating wounds: removal of foreign bodies, rejoining of severed tissues, maintenance of tissue continuity, preservation of organ substance, and prevention of complications. De Chauliac described a weighted system for continuous traction to reduce femoral fractures. He also was an early advocate of topical anesthesia [79] and described techniques for hernia, cataract, and amputation [41].

The development of firearms made cautery a universally accepted treatment for gunshot wounds throughout the 16th century. Gunshot wounds resulted in gross tissue destruction that was an excellent medium for infection. However, because surgeons of the era had no knowledge of bacteria, they concluded infection was the result of poisonous gunpowder, and sought to destroy the poison by pouring boiling oil into the wound [116]. The precise origin of this practice is uncertain, but it was widely popularized through medical texts written by an Italian surgeon, Giovanni da Vigo (1460-1525) [41]. During the siege of Turin in 1536, Ambroise Paré (1510-1590), a surgeon with the French Army, ran out of boiling oil and substituted a salve of egg yolk, oil of rose, and turpentine, which, to his astonishment, reduced inflammation and enhanced patient comfort, at least compared with "seething oil" [7]. He concluded conventional wisdom was incorrect and published his observations in his Treatise on Gunshot Wounds in 1545.

During the American Revolutionary War, surgeons from the British and American sides emphasized conservative care. John Hunter (1728-1793), surgeon general of the British army, directed physicians to resist aggressive
Washington, DC.) (B) More seriously wounded patients are loaded onto a C-17 "flying ICU" in March 2007 for transport out of Iraq to Level IV facilities. (Photograph by Tech Sgt Mike R. Smith. Courtesy of the National Guard Bureau, Arlington, VA.)

débridement in smaller wounds. Wine was applied topically to minor burns, and hog lard to full-thickness burns [96]. John Jones (1729-1791), a veteran of the French and Indian Wars (1754-1763) and Professor of Surgery in King's College, New York, advised surgeons to delay primary wound closure and apply:

... nothing but dry, soft lint to recent wounds; which is generally the best application through the whole course of the cure. At first it restrain the hemorrhage with less injury than any styptic medicines; and afterwards, by absorbing the matter, which is at first thin and acrimonious, it becomes, in effect, the best digestive. During incarnation (granulation) it is the softest medicine than can be applied between the roller and tender granulations; and at the same time an easy compress on the sprouting fungus. For these reasons I shall not recommend to you any ointments for recent wounds, unless some mild, soft one, to arm a pledget of tow, to cover the lint. ... Incised wounds are to be brought together with sticking plaster and bandages. The use of a suture is unnecessary in longitudinal wounds. Transverse wounds require the suture. The interrupted suture is used and the needle dipped in oil. A plaster is applied over the sutures, which may usually be removed in two or three days [40].

Bullets were removed only if within easy reach of the surgeon. If a wound had to be closed, a piece of onion was placed in the cavity before closure, and the wound 
reopened in 1 to 2 days. As in the past, Colonial physicians saw the development of pus a few days after injury as a sign of proper wound digestion [96].

By the time of the Crimean War, wound management had changed little in a conflict that saw the first use of the Minié ball in combat. These bullets traveled at a higher velocity and struck the body with greater force, shattering bone into small fragments and causing extensive soft tissue damage. The resulting compound fractures, as noted by Dr. George Macleod (1828-1892), a staff surgeon at a general hospital in Sebastopol, the Ukraine, forced British surgeons to learn hard lessons:

Of all the severe injuries recorded in battle, none are of more frequent occurrence or of more serious consequence than compound fractures. ... In the Crimea, these injuries were peculiarly embarrassing and extraordinarily fatal. ... It can hardly be doubted that the great striving after conservatism, which influenced all the surgeons of our army, was one main cause of that mortality which attended these injuries [90].

Hemorrhage was classified as primary, occurring within 24 hours of wounding; intermediate, occurring between the first and tenth days; and secondary, occurring after the tenth day. Macleod [90] believed a patient was vulnerable to hemorrhage until the wound had fully closed but was unlikely to have problems 24 days after wounding.

The devastating trauma caused by the Minié ball was seen on a much larger scale during the US Civil War. Fatality rates were high for penetrating gunshot wounds to the abdomen (87\%) and chest (62\%) [12]. Early in the war, cautery and tourniquets were the primary approach to controlling hemorrhage, but as physicians grew more experienced, ligature became the primary means for hemostasis. Primary hemorrhage became rarer, but intermediate hemorrhage, after 3 or 4 days, was more frequent and carried a mortality rate of $62 \%$ [13].

Although von Esmarch is rightly remembered for his improvements in organization and evacuation, his most famous innovation was the triangular Esmarch bandage ("Dreieckstück" or "triangular piece"), a piece of cotton twice as long at the base as along the sides, which can be folded in numerous ways to act as a dressing or sling [42]. von Esmarch also urged the use of ice packs to reduce inflammation in wounds, leading colleagues to give him the nickname "Fritz the Ice Pack" [42].

The Spanish-American War (1898) was notable for the introduction of smaller-caliber, high-velocity, metal-jacketed bullets, which were first used in the Battle of Santiago, Cuba, on July 1, 1898. The metal-jacket bullet was conceived as a more humane form of ammunition that would produce cleaner wounds and less deformation [51]. This was not the case, as a higher-velocity missile turned out to produce greater cavitation and extensive soft tissue damage beyond the path of the bullet [147].

The British orthopaedic surgeon, Robert Jones (18571933), applied lessons from his medical family and his civilian work to great effect during World War I. Jones' uncle, Hugh Owen Thomas (1834-1891), first described the use of braces and splints in fracture management in his 1875 book Diseases of the Hip, Knee and Ankle Joints [55]. Robert Jones began practicing medicine in 1878 and a decade later became surgeon for the massive, 7-year Manchester Ship Canal Project, which involved 20,000 workers and provided numerous opportunities to practice new techniques in fracture care. By the time World War I began, Jones had narrowed his practice from general surgery to orthopaedics and became director general for orthopaedics for the British military. At this point, the death rate from battlefield fractures of the femur was approximately $80 \%$. In response, Jones reintroduced his uncle's splint to immobilize the leg immediately on the battlefield. Medics and stretcher bearers were blindfolded during training sessions so that they would be ready to apply the splint in total darkness. By 1915, better immediate management of femur fractures had reduced the mortality rate to approximately $20 \%$ [55].

In 1945, the Office of the Surgeon General summarized the general approach to wound care during the Second World War:

As the initial wound operation is by definition a limited procedure, nearly every case requires further treatment. Soft part wounds, purposely left unsutured at the initial operation, are closed by suture, usually at the time of the first dressing on or after the fourth day. Fractures are accurately reduced and immobilized until bony union takes place. Designed to prevent or cut short wound infection either before it is established or at the time of its inception, this phase in the surgical care of the wounded is concerned with shortening the period of wound-healing and seeks as its objectives the early restoration of function and the return of a soldier to duty with a minimum number of days lost [102].

The major change in the evaluation of wounds during World War II involved the timing of closure. In World War I, surgeons learned the value of delayed primary closure in aiding recovery and fighting infection. Cultures would be the main determinant of whether a wound was ready for closure. However, physicians found judging the clinical appearance of the wound-whether tissues looked healthy, with absence of drainage, foreign material, and edemaled to better results. Edward D. Churchill (1895-1972), a US surgeon in the Mediterranean and North African 
theaters, reported in 1944 that 25,000 soft tissue wounds from battle in North Italy had been closed based solely on appearance, with only a 5\% failure rate [28]. Cleveland and Grove [32], in a series of 2293 closures over compound fractures in patients evacuated to Britain, found $93 \%$ of wounds healed successfully when judged in this fashion instead of relying solely on cultures.

In Korea, combat medics worked effectively to resuscitate wounded before they were transported by helicopter and truck. Pressure dressings were applied as a first resort to control bleeding; guidelines stated tourniquets should be used only if pressure dressings were not sufficient. Fractures were splinted and wounded extremities immobilized. The medic may have begun antibiotic therapy if the casualty could not be transported for 4 to 5 hours. Blood was transfused before evacuation [128]. Extremity wounds were débrided and left open and fixed with Küntscher wires and plaster [5].

During the Vietnam War, semiautomatic rifles with high-velocity rounds caused considerable soft tissue damage, complicating wound care. Patients frequently sustained multiple wounds from bursts of automatic fire or booby traps. Surgeons could receive patients as early as 1 to 2 hours after wounding [60,96], although in reality conditions during combat often delayed evacuation and resulted in an arrival time of 4 to 6 hours after wounding. On arrival, the patient was infused with Ringer's lactate and antibiotics. The wound was débrided and lavaged and packed open with occlusive dressings. Patients with fractures and vascular injuries typically were treated by vascular and orthopaedic specialists. Fractures were treated by reduction and initial traction or casting depending on the severity of the wounds. Secondary closure of the wound usually could be accomplished in 7 days. Wounds with massive soft tissue damage were covered with occlusive dressings or a mesh graft. Innovations included increasingly sophisticated vascular repair and treatment of hypovolemic shock [115].

The nature of wounds sustained by service members in Iraq and Afghanistan has been transformed by suicide bombers, and Improvised Explosive Devices (IEDs) have contributed to limb amputations as a result of massive tissue damage from explosives. In Iraq and Afghanistan, resuscitation begins on the battlefield (Level I) and continues during transport. Tourniquets and advanced hemostatic dressings, such as HemCon ${ }^{\circledR}$ (HemCon Medical Technologies, Inc, Portland, OR) and QuikClot ${ }^{\mathrm{TM}}(\mathrm{Z}$ Medica, Newington, CT), also are used in the field. Depending on battle conditions, the wounded may reach a Level II or Level III facility in 30 to 90 minutes [126]. Care at Level II facilities is limited to damage control, such as the placement of vascular shunts and stabilization, whereas Level III facilities can provide definitive repair of arterial and venous injuries using autologous vein, with a goal of definite repair of vascular injury before evacuation from Iraq [119]. Once at the Level IV or V facilities, wounds are evaluated and definitive fixation of injuries occurs. When limbs can be saved, internal and external fixation methods are incorporated. Fracture patterns and the extent of the soft tissue injuries dictate fixation type. External fixation is used when an extended amount of time is needed for repeated débridement. A combination of internal and external fixators is used with injuries to upper extremities. Tibia fractures frequently require external fixation, whereas femur fractures generally are treated with intramedullary rods. In the case of lower extremity periarticular fractures, a combination of internal and external fixation often is useful. Free flaps and rotational flaps are used to provide soft tissue coverage, along with the relatively new innovation of secondary-intention wound granulation through vacuum-assisted closure dressings and hemostatic bandages [3].

\section{Surgical Techniques and Technology}

Amputation has been performed since ancient times, as observed by Peruvian votive figures and Egyptian mummies. Hippocrates advocated amputation of gangrenous limbs, although he advised removing them through, not above, the gangrenous area [84]. The Roman Celsus (circa 3-64 CE) later observed the border between healthy and sick tissue was the proper demarcation line [84]. Before the invention of gunpowder in the 14th century, wounds were caused by cutting, stabbing, and blunt force, and the injured often lived without major surgical intervention. As musculoskeletal injuries from shot and cannon grew more complex, surgeons gained greater experience with the art of amputation.

As noted above, the French surgeon Paré found "seething oil" need not be used in cauterizing wounds. More important was his observation that bleeding after amputation could be stopped by ligating blood vessels instead of applying red-hot irons. He developed a procedure for tying off veins and arteries that made thigh amputations possible. He published his technique in 1564 , imploring surgeons to abandon entirely "the old and cruel way of healing" with cautery [7]. Using Paré's methods, limb amputation remained the most common treatment for extremity wounds, as it transformed a complex wound into a simple wound with a better chance of recovery. Throughout his long career, Paré served in at least 17 military campaigns and was personal surgeon to four kings of France. During the Battle of Metz, the besieged French soldiers allegedly exclaimed, "We shall not die even though we are wounded. Paré is with us" [53]. His 
conservative methods revolutionized care and likely spared thousands from suffering [73].

The normal practice through the 16 th and 17 th centuries was the single circular cut. Through the 18 th century, the treatment of wounds had advanced little since Paré, until two innovations by Jean Petit (1674-1750). Petit introduced the two-stage circular cut, in which the skin was transected distal to the planned level of amputation and pulled up. The muscles and bone then were cut at the same level proximally. This technique was adopted and refined by English, Austrian, and Prussian surgeons [92, 125]. Petit's second contribution was the modified tourniquet, with a screw to adjust tension, making bleeding during an amputation manageable (Fig. 6) [60]. During the late 17th century, English and German surgeons also began to experiment with soft tissue flaps to cover the bone, a technique used routinely by England's Robert Liston (1794-1847) by 1837 [91].

One of the ongoing controversies regarding amputation throughout history was timing the procedure. Britain's John Hunter, in line with his conservative approach,

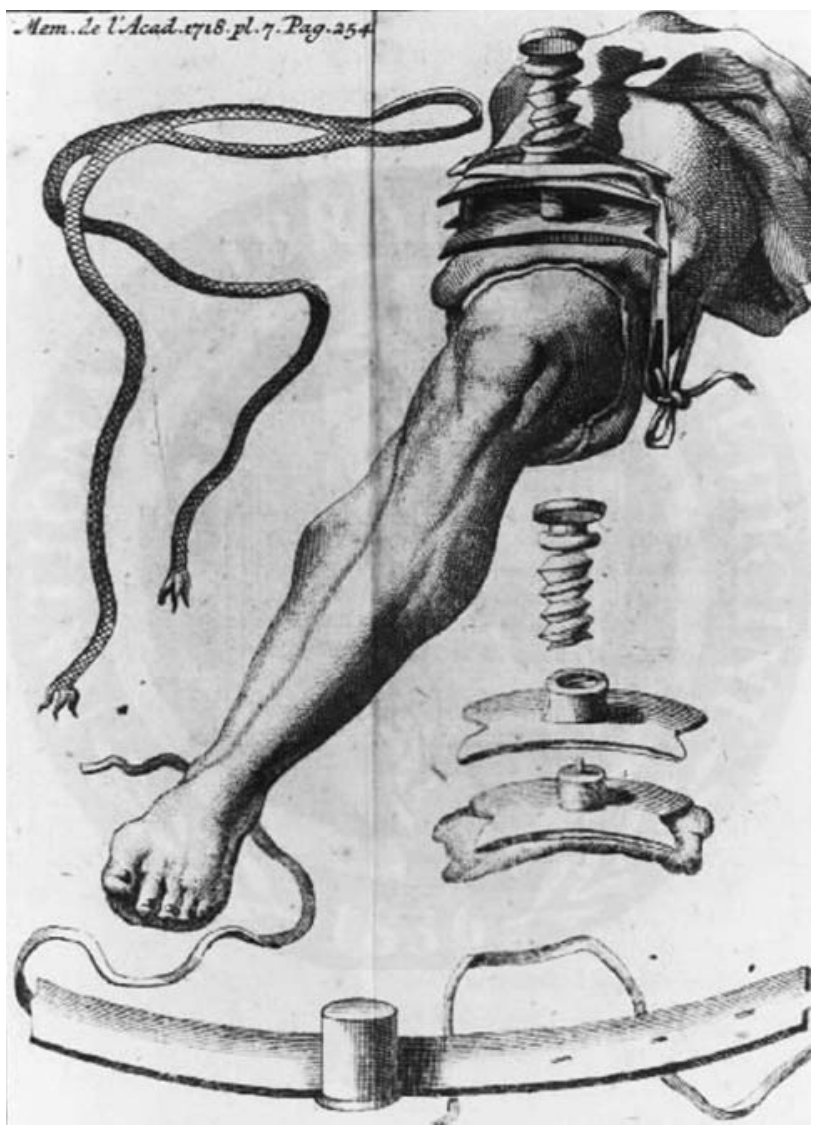

Fig. 6 Jean Petit's screw tourniquet offered a more practical means to control bleeding during amputation. This engraving from 1718 shows a leg with the tourniquet attached and vignettes of the tourniquet apparatus. (Courtesy of the National Library of Medicine, Washington, DC.) advised against amputation on 18th century battlefields, believing more time was needed for inflammation (what we now know as septic contamination) to ease before surgery [67]. In contrast, France's Larrey urged immediate intervention. He ordered primary amputation within 24 hours for all ballistic wounds with injuries to major vessels, major damage to soft tissue, and comminuted bones. He also performed complete débridement to provide the best possible stump and advised leaving the stump end open, covered only with a light bandage [84]. Although largely known for his organizational skills, Larrey was one of the most accomplished surgeons of his time and certainly must have been among the fastest, as he is credited with performing 200 amputations in a 24-hour period during the Battle of Borodino (1812) [61]. He also performed the first successful disarticulation of the hip [84].

The Crimean War was the first major conflict in which chloroform was widely used as an anesthetic [33]. Although ether had been used on a limited scale by the US Army in the Mexican-American War [1, 72] (1846-1848) and by the Imperial Russian Army during a pacification campaign in the Caucasus region [95], the inherent flammability made its utility questionable in a battlefield hospital. News of anesthesia's successful application in battlefield surgery profoundly influenced its increasing acceptance in civilian settings [95]. An additional innovation was the use of plaster of Paris as a support for broken bones [140].

During the US Civil War, amputation was the most common surgical procedure for the 60,266 Union patients who sustained gunshot fractures [123]. Mortality for amputation of the lower limbs overall was 33\%, and above the knee it increased to 54\% [123]. Although surgeons of the era were aware of flap techniques and some Union surgeons used them [84], circular amputations were preferred for better control of hemorrhage [56] and were performed at the level of injury to preserve length. At the beginning of the war, Samuel Gross (1805-1884), Professor of Surgery at Jefferson Medical College, noted amputation was more likely to be successful if performed as soon after injury as possible, at least 12 to 24 hours after injury [104]. Wartime experience proved this observation as the fatality rate of patients with 16,238 amputations of upper and lower extremities by primary amputation (within 48 hours of wounding) was $23.9 \%$ compared with a $34.8 \%$ mortality rate among patients with 5501 intermediate amputations (between 2 days to a month) and $28.8 \%$ for patients with secondary amputations (after a month) [104]. He cautioned against procrastination, urging surgeons to decide on the course of treatment using the best information available [104]. Before the war, few American surgeons would have attempted to operate on major blood vessels, but by the war's end, thousands of physicians were 
experienced in tying an artery [124]. Surgeons made early attempts at open reductions or excisions, albeit with a $27 \%$ fatality rate, despite the fact that the majority of cases were performed on upper extremities. Sixty-six complex hip disarticulations were performed, with an $88 \%$ mortality rate for primary amputations, $100 \%$ for intermediate amputations, and $55.5 \%$ for secondary amputations (Fig. 7) [104]. Anesthesia was used extensively. Surgeons used chloroform in approximately $75 \%$ of cases in which anesthesia was used; ether or a mixture of ether and chloroform was used in other cases.

Military surgeons were quick to adopt the use of radiographs after Wilhelm Conrad Roentgen's (18451923) discovery of xrays in 1895 [81]. Only 5 months later, Italian physicians in Naples used radiographs to locate bullets in soldiers wounded during their country's invasion of Abyssinia (modern Ethiopia) [30]. During the GrecoTurkish War of 1897 (also known as the Thirty Days' War), German (on the Ottoman side) and British (on the Greek side) physicians used the new technology [30]. Less
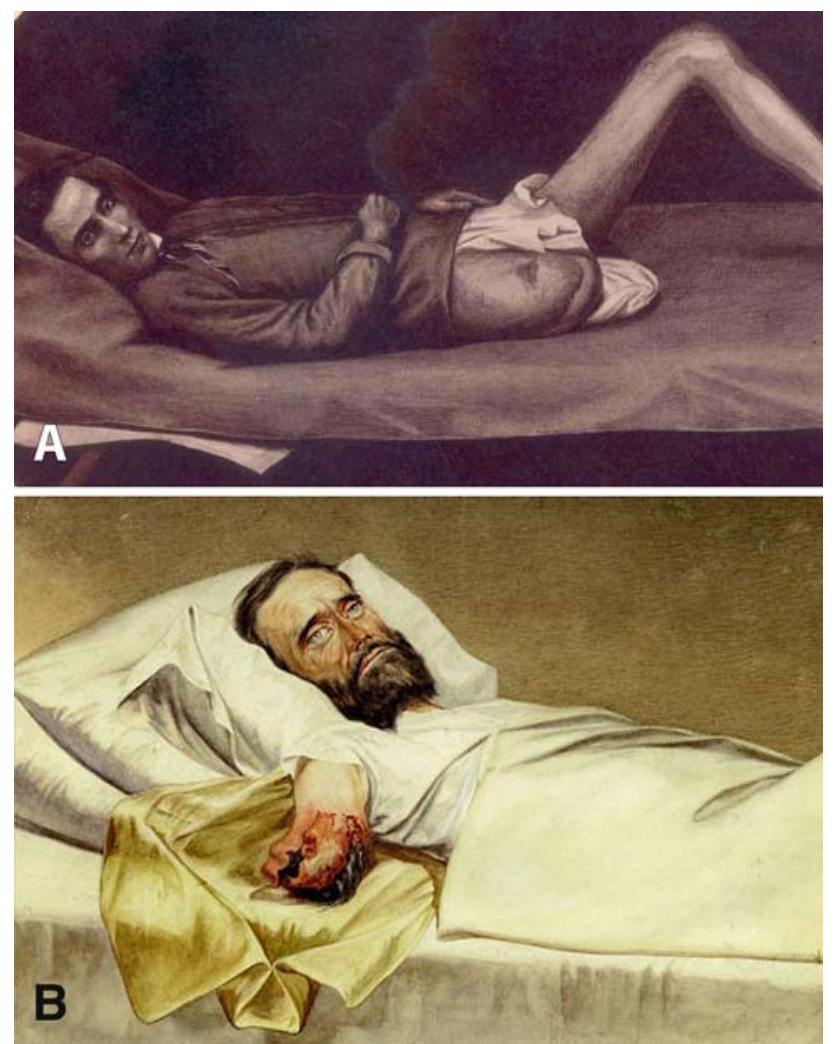

Fig. 7A-B (A) A drawing depicts a successful secondary amputation at the right hip in a Union soldier, circa 1864. (Courtesy of Otis Historical Archives, National Museum of Health and Medicine. Armed Forces Institute of Pathology, Washington, DC.) (B) Another drawing shows hospital gangrene of an arm stump. The private, who was wounded by a Minié ball, was imprisoned in Richmond, VA, on July 4, 1863. (Courtesy of Otis Historical Archives, National Museum of Health and Medicine, Armed Forces Institute of Pathology, Washington, DC.) than 3 years later, during the Spanish-American War, the US Army placed xray machines onboard three hospital ships in the theater of operations [10]. Surgeons no longer were compelled to locate bullets by probing, improving antiseptic practice, and radiographs revealed the nature of fractures in detail previously unimaginable [43]. Despite the radiograph's revolutionary role, and its rapid incorporation into US military medicine during the war, the teaching and practice of radiology among military physicians languished until 1917, when the leadership of the American Roentgen Ray Society successfully petitioned the War Department to create 10 centers for physician and technician training [30].

As Paul Dougherty noted, the American Expeditionary Force's relatively late involvement in World War I led to reliance on the experience of the British and French physicians on the Allied side [37]. During the war, a Belgian surgeon, Antoine Depage (1862-1925), realized the current approach of minimal wound exploration and primary closure was insufficient. He believed dead tissue led to infection and must be removed, and infection decreased if the wound were left open to air for a time. Antiseptics were an essential part of wound care but could not replace thorough débridement and removal of foreign material [66]. After poor results from primary closure early in the conflict, Allied surgeons began using the open circular technique with better results and flaps constructed to ease closure. Most frequently, wounds were left open for 24 to 48 hours and then closed if bacterial counts were low and the wound's appearance indicated it was not infected. If higher bacteria counts were detected, the wound was reopened and irrigated with Dakin's solution (see below). Delayed closure also allowed surgeons to experiment with other surgical techniques, such as leaving bone fragments in place in patients with compound long-bone fractures. A half century of improved surgical and antiseptic techniques meant, from the time of the Civil War to World War I, the rate of major amputations as a percent of all battle injuries had decreased from $12 \%$ to just $1.7 \%$ [114]. Postoperative care also was improved, as seven amputee centers were established across the country to provide specialized surgery, therapy, and prosthetics [37].

US entry into the conflict required the mobilization of thousands of surgeons who had limited experience with wartime amputation. A review of amputations of casualties at Pearl Harbor showed infections from early primary closure of the stump, open amputations performed at a higher level than necessary, and failure to provide skin traction [109]. In 1943, Kirk, a veteran of World War I and expert on amputations, became the first orthopaedic surgeon to serve as surgeon general. Kirk's published recommendations before his appointment were essentially the same as Army guidelines, emphasizing the open 
circular technique, where skin and soft tissues are left slightly longer than the bone, and double ligation of blood vessels and delayed plastic closure [85]. Amputation was to be performed at the lowest level of viable soft tissue to preserve length for further revision surgery. If the patient was not to be moved, flaps could be constructed to allow for closure later. Skin traction was required after surgery through evacuation. There were some variations from theater to theater with time regarding whether sulfa powder would be applied to wounds, and the practice was abandoned by D-Day (see below) [37]. US military guidelines changed as circumstances warranted. For example, before the invasion at Normandy in June 1944, surgeons destined for the European theater were instructed they would be allowed to use either the open circular method or the true guillotine (in which fat, muscle, and bone were divided at the same level). Just a month after the landing, based on real-time experiences, only the former technique was recommended. Likewise, earlier in the war, Vaseline gauze was used to dress the wound; by 1944, fine-mesh gauze was mandated to allow for better drainage [37]. As during World War I, the Army and Navy established specialized centers in the United States to provide for amputee's postmilitary rehabilitation (The centers have continued through today in the Armed Forces Amputee Patient Care Program, with facilities in Washington, DC; San Antonio, TX; and San Diego, CA.) [114].

Fracture care also evolved during World War II. Early methods of external fixation, using pins and plaster rather than the complex devices seen today [4], had become more widespread in civilian settings in the 1930s and initially were used by the US Army and Navy overseas. However, many military physicians were still inexperienced in the management of fractures by external fixation, and of the 25 patients treated with external fixation in the Mediterranean theater, four had infections develop, and a fifth experienced "bowing and slough at the pin site" [38]. Discouraged by early results, the US Army under Kirk's leadership did not use external fixation for most of the war, even as Navy physicians reported good results [129]. Through the conflicts in Vietnam and Korea, the US Army prohibited the use of external fixation, even in the treatment of massive soft tissue wounds. Instead, from the end of World War II until the early 1970s, functional casting was the official technique for managing long-bone fractures [127]. The US Army's objections to external fixation meant that a generation of orthopaedic surgeons had no opportunity to learn the practice in wartime. A 1950 survey by the American Academy of Orthopaedic Surgeons showed that only $28 \%$ of respondents believed external fixation had a role in fracture management [130].

A major innovation in the treatment of fractures came from a German surgeon, Gerhard Küntscher (1900-1972), who in the late 1930s developed the practice of intramedullary nailing for long-bone fractures. The onset of war in 1939 prevented the dissemination of Küntscher's techniques to Western Europe or the United States, but American surgeons became aware of his work from captured Allied airmen treated by intramedullary nailing during captivity. The procedure was controversial among US surgeons and was not used until the Korean War [39]. Brav and Jeffress [16] reported good results from intramedullary nailing on eight patients with femoral fractures from gunshot wounds but recommended it be reserved for patients who did not respond to traditional traction and suspension. Intramedullary nailing gained gradual (sometimes grudging) acceptance in civilian practice through the 1960s and 1970s [26], and in the 1990s was the subject of renewed interest with improvements in implants and technique [142].

One of the most notable contributions of Surgeon General Kirk's leadership was the recruitment of his long-time colleague, A. Sterling Bunnell, MD (1882-1957) (Fig. 8), to create the US Army Hand Centers in late 1944. While touring stateside hospitals, Kirk had become alarmed by the

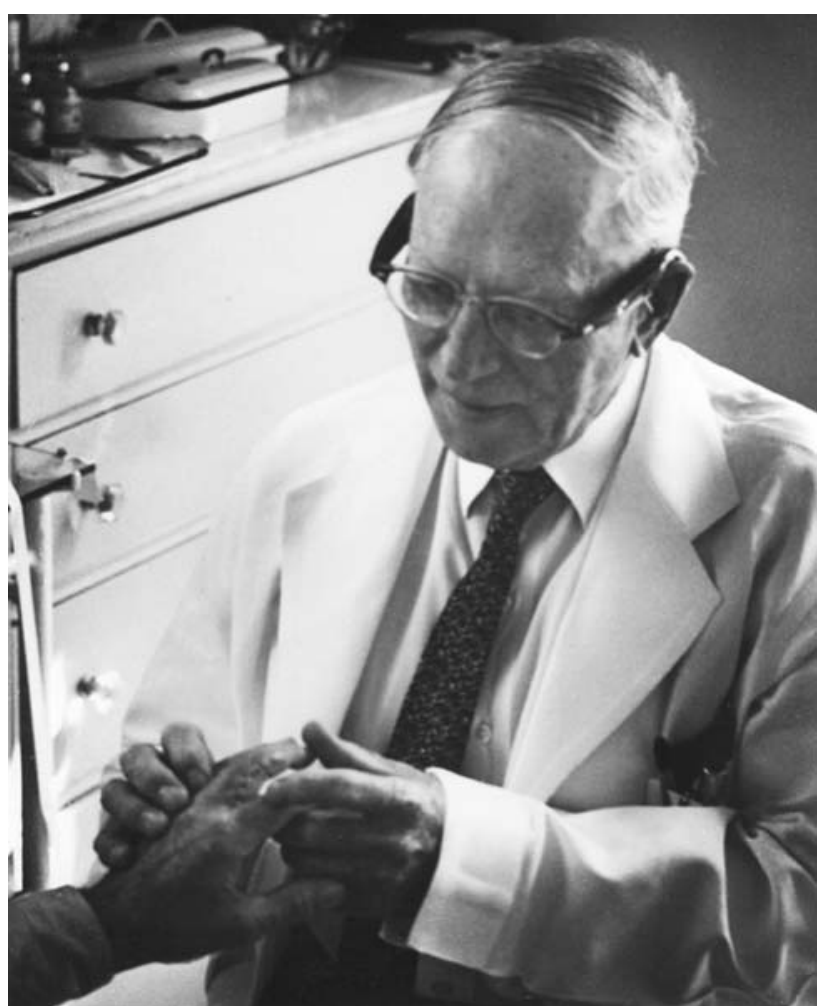

Fig. 8 Sterling Bunnell, MD, had completed the first edition of Surgery of the Hand [20] when called on by Surgeon General Kirk to create US Army Hand Centers in 1944. His work, particularly in training dozens of protégés, laid the foundation for the subspecialty of hand surgery. (Courtesy of Sterling Bunnell Memorial Library, Health Sciences Library, California Pacific Medical Center, San Francisco, CA.) 
lack of efforts to salvage crippled hands. Posttrauma care of hand wounds was provided routinely by various specialists: orthopaedists, plastic surgeons, and neurosurgeons. Bunnell, who had just finished the first edition of his huge work, Surgery of the Hand [20], seized the opportunity to create the specialty of hand surgery [25]. At the 10 hand centers he directed, young physicians, many of them just out of surgical training, developed most of the techniques still used today: tendon transfer, nerve repair, skin grafts, arthrodesis, and osteotomy [18, 21, 25]. One of those physicians, Paul Brown, pioneered the use of Kirschner wires to provide fixation for closed and open complex hand injuries; his techniques are still used today [19].

Vascular surgery, an experimental procedure during World War II, became routine in Korea as Edward J. Jahnke (born 1923) trained surgeons to use the procedure, reducing the amputation rate attributable to vascular injury from $49.6 \%$ during World War II to $20.5 \%$ during the Korean War [139].

As the care of the wounded became routine, surgeons began to devote their attention to cases that would have resulted in certain death in previous wars. A Renal Insufficiency Center, complete with a Kolff-Brigham Artificial Kidney, treated 51 patients at the 11th Evacuation Hospital in Korea [73]. Improved resuscitation and transport meant $0.5 \%$ of patients suffering from shock who would have died lived long enough to suffer acute renal failure because of fluid volume overload and/or myocardial potassium intoxication [87]. The mortality rate among these patients was reportedly as high as $90 \%$ [135]. When dialysis was introduced in 1951, the mortality rate later decreased to $53 \%$ [27]. Studies between the Korean and Vietnam conflicts showing the importance of fluid balance during shock informed changes in practice that led to a reduced incidence of renal failure $(0.17 \%)$ in Vietnam casualties [23, 35]. Generally, dialysis was effective for patients with major musculoskeletal injuries who otherwise were healthy; acute renal failure occurred mostly in patients who had multiple complications after wounding [143].

In both World Wars and Korea, artillery was the deadliest threat to soldiers. In Vietnam, because the enemy had relatively little heavy weaponry, most injuries were caused by machine gun fire, mines, and booby traps. As a consequence, the rate of major amputations as a percentage of all battle injuries actually increased to $3.4 \%$ from $1.4 \%$ in Korea and $1.2 \%$ in World War I [114]. Blast injuries, often from beneath the injured soldier, caused deep penetration of foreign material into the thigh and often hips and knees. After battlefield evacuation, usually by helicopter, surgeons evaluated the wound, and the decision to amputate was made by an orthopaedic specialist. The open-flap amputation was the preferred procedure, with delayed closure, although the circular method also was allowed.
Amputation was performed at the most distal point, with all nonviable tissue débrided [8]. Although experience from previous wars and official recommendations called for continuous skin traction, a 1970 study of 300 amputees indicated only $44 \%$ had been treated with some form of skin traction [145]. Pins and plaster were applied before evacuation to a stateside hospital.

Colonel Norman Rich (born 1934), chief of surgery in a MASH unit in Vietnam's central highlands, pioneered venous repair for military trauma, increasing the chance of saving badly wounded legs $[121,122]$. On his return to the United States, he established the Vietnam Vascular Registry, which has records from more than 7500 cases and still is used today [117, 147].

In today's military, enhanced body armor and modern resuscitation have increased survival rates for patients with blast wounds that previously would have been fatal. This positive development poses a challenge for surgeons treating the wounded from Afghanistan and Iraq, particularly in the realm of limb salvage. Owens et al. [107] studied 1281 wounded from 2001 to 2005. The soldiers sustained 3575 extremity combat wounds, with $53 \%$ penetrating soft tissue wounds and 26\% (915) fractures. Open fractures comprised $82 \%$, or 758 , and were evenly distributed between the lower and upper extremities. Three-quarters of the injuries were caused by explosive devices [107].

The care of patients who have sustained IED wounds is complex; trauma, burns, blood loss, devitalized tissue, and embedded fragments of the explosive along with rocks, dirt, glass, and debris can be present. Damage control resuscitation performed by military surgeons recognizes a successful outcome depends on more than merely treating the wound. Blood chemistry needs to be stabilized, hypothermia must be prevented, and systolic blood pressure maintained at $90 \mathrm{~mm} / \mathrm{Hg}$, in addition to controlling bleeding, removing foreign bodies, débridement, and fracture fixation [100].

Current guidelines no longer call for circular amputation but (as in the past) emphasize the need to preserve maximum length for later preservation. The patient undergoes thorough surgical débridement within 2 hours of injury and redébridement every 48 to 72 hours through evacuation. No viable tissues are removed, and the level of soft tissue injury (not the fracture) determines the amputation level. Wounds are left open through transport; no skin traction is used because of the relatively short evacuation time, although negative pressure dressings have been used at sites along evacuation routes to the continental United States [64]. Once stateside, the patient is evaluated, and débridement is continued until the wound is ready for delayed closure. A now greatly expanded rehabilitation program, with the aid of prosthetic devices using digital 
technology, assists amputees in their return to civilian life or, in at least 30 cases so far, to active duty [47, 64].

\section{Blood Transfusion}

The Austrian Karl Landsteiner (1868-1943) and coworkers described blood types $\mathrm{A}, \mathrm{B}$, and $\mathrm{O}$ in 1901, and the $\mathrm{AB}$ blood group in 1902 [149]. Subsequent blood typing greatly reduced the potential complications of blood transfusion. Expanded transfusion offered the promise of preventing many fatalities of war caused by or complicated by blood loss. It also posed medical and logistic challenges to military caregivers.

The British Army began routine use of blood transfusion for treatment of combat casualties. In 1916, surgeons performed direct transfusions on patients whose conditions were considered desperate. Of the 19 casualties it was tried on, 15 died. Despite the inauspicious start, surgeons with the British Second Army routinely performed direct transfusions on patients using a syringe cannula technique. In November 1917, American surgeon Captain Oswald Robertson (1886-1966) concluded it would be better to stockpile blood before the arrival of casualties. He collected $500 \mathrm{~mL}$ of blood from each donor and stored it in an icebox to be administered to a patient 10 to 14 days later. Blood could be stored and transported to be administered at casualty clearing stations close to the front, creating the first blood bank [82].

Despite the lessons of World War I, many surgeons still believed shock was caused by inadequate arterial pressure rather than inadequate capillary perfusion. Although the British had entered the war with large quantities of blood and plasma and Charles Drew (1904-1950) of the American Red Cross had developed an international blood collection and distribution system for the Blood for Britain campaign of 1940 [50], the US Army had no blood banks, and when blood was given, it was only in small amounts (100-150 mL) [59]. After heavy losses in North Africa, military surgeons recommended a blood bank be instituted. However, the Surgeon General's office balked, citing logistic concerns and stating plasma was adequate [59]. Under the leadership of US Surgeon General Kirk, an organized system to provide whole blood transfusions instead was developed by army field hospitals in 1943 and 1944. By the second half of 1944, with huge numbers of soldiers in the field across Europe and in the Pacific, army policy finally changed to provide air shipments of whole blood from the United States. By March 1945, the army was shipping 2000 units a day (Figs. 9, 10) [68]. The system was implemented rapidly, was highly efficient, and doubtless saved thousands of lives but was completely dismantled by the onset of the Korean War.

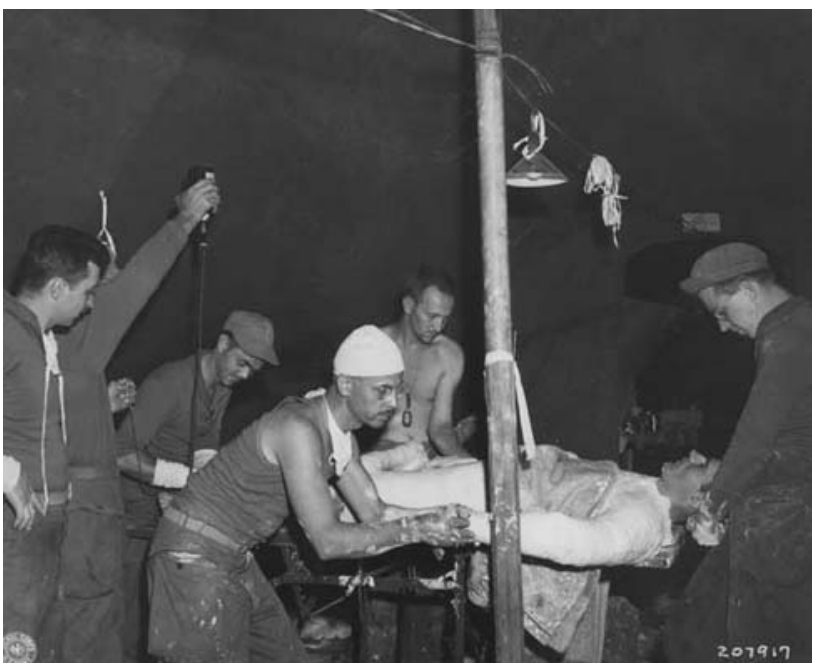

Fig. 9 In a hastily constructed tent on Okinawa, US 10th Army medics complete a cast on a soldier wounded by shell fragments. Assistants, meanwhile, administer blood plasma. This photograph was taken on April 9, 1945. (Courtesy of Otis Historical Archives, National Museum of Health and Medicine, Armed Forces Institute of Pathology, Washington, DC.)

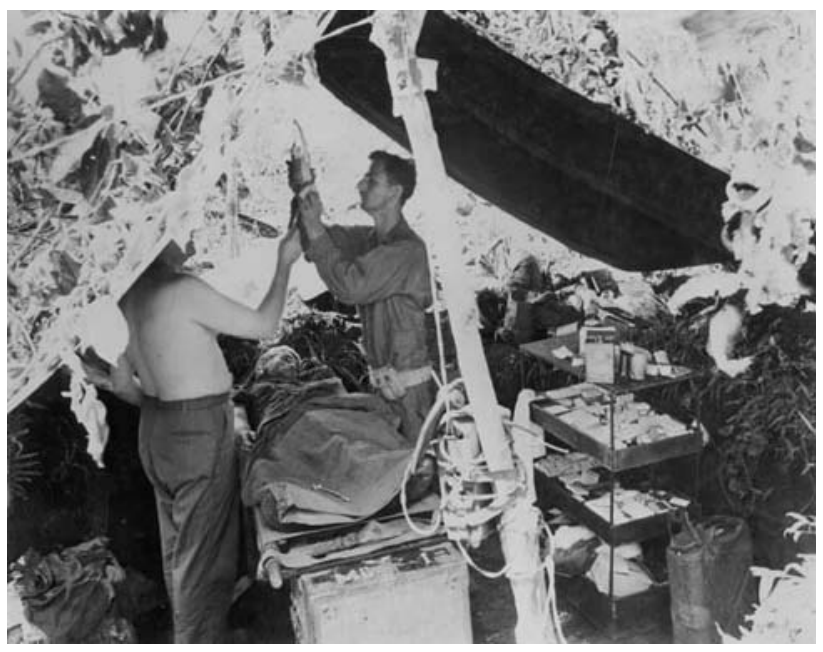

Fig. 10 Blood plasma is given to the wounded at a medical station near the front line somewhere in the South Pacific during World War II. (Courtesy of Otis Historical Archives, National Museum of Health and Medicine, Armed Forces Institute of Pathology, Washington, DC.)

At the outbreak of fighting in Korea, with the US military in rapid retreat, collections stateside were shipped to the 406th General Medical Laboratory in Tokyo. Type O was greatly preferred to eliminate the need for crossmatching, specialized technicians, and larger stocks. According to the Armed Services Blood Program (ASBP) records, only four major hemolytic reactions resulting in acute renal failure were reported of approximately 50,000 transfusions in 1952. All four were attributable to locally 
acquired blood. The most lasting legacy of the Korean War regarding blood transfusion may be the introduction of plastic bags rather than glass bottles, better enabling preparation of components and, by eliminating breakage, ensuring more units reached troops. The Military Blood Program (today's ASBP) was established in 1953 [2].

US military blood programs reflected the experience in Korea during the early years of engagement in Vietnam. Approximately every 10 days, units of Type $\mathrm{O}$ blood were shipped from Japan [83]. As the American military commitment grew by April 1965, the Army established a central blood bank in Saigon, with four subdepots across the country, and greatly broadened the collection of blood to reduce shortages. Every unit used to support the war was donated voluntarily by military personnel, dependents of military personnel, and civilians working on military bases-approximately 1.5 million donors and 1.8 million units of blood. For the first time, forward medical units received all four types of blood. The ASBP coordinated collection stateside, and blood was processed at McGuire Air Force Base in New Jersey before shipping to Vietnam. Blood also was collected from volunteers representing all services in Okinawa, Japan, and Korea and distributed by the 406th Mobile Medical Laboratory in Saigon [14].

After Vietnam, the US military maintained its capacity to collect, package, and transport blood. Improvements in anticoagulants and technology to freeze blood greatly enhanced its efforts. During the 1991 Gulf War, the ASPB shipped more than 100,000 units to troops in theater and currently operates 21 donor centers and 81 transfusion centers in the United States, Europe, and Asia [2].

\section{Infection and Antibiotics}

In the 18th century, infection control was not considered an issue, because physicians assumed disease was caused by an imbalance of humors rather than microbes. However, surgeon Charles Gillman, after accidentally spilling rum on the badly infected hand of a soldier wounded in the Battle of Harlem (1776), noted the infection resolved rapidly, an observation consistent with Hippocrates' recommendation to use wine to irrigate a wound [116]. Yet, the practice was never adopted by the Continental surgeons.

Gunshot wounds continued to be treated as inherently infected by gunpowder until Hunter published his Treatise on Blood, Inflammation, and Gunshot Wounds [75] in 1794. He argued a bullet wound should be treated like any other wound [54], although he cautioned against wound exploration, débridement, and splinting. Physicians throughout the late 18th and early 19th centuries continued to experiment with various compounds to prevent the spread of infection in patients with compound fractures, including wood tar, chlorine, tincture of benzoin, silver nitrate, and various alcohol solutions [116].

The Civil War famously showed the value of sanitary practices, or the consequences of their absence. Contrary to popular belief, surgeons usually washed, but did not disinfect, their hands and surgical instruments. The surgeon typically operated bare-handed, wearing his regular uniform or civilian garb protected by a butcher's apron. Surgery generally was performed outdoors to take advantage of sunlight. The aseptic environment of 21 st century hospitals was not even a concept during the Civil War [15]. Suppuration still was regarded as a sign of proper healing rather than a risk for pyemia $[12,13]$. Even so, death was more likely to come from a camp-acquired disease than from a battlefield wound. Of the generally accepted number of approximately 620,000 deaths among Union and Confederate forces, about two thirds resulted from disease, most prominently dysentery and typhoid [104].

The most feared wound infections were erysipelas, presumably attributable to Streptococcus pyogenes, and hospital gangrene. Physicians did not agree on the cause or treatment for erysipelas, which carried a mortality rate of $8 \%$. The battle against hospital gangrene and its $60 \%$ mortality rate [96], however, produced one of the rare antiinfection victories of the war. In 1863, the Union medical officer Middleton Goldsmith (1818-1887), stationed in Louisville, $\mathrm{KY}$, reported the results of a treatment protocol that called for débridement of all necrotic tissue and application of a mixture of bromine, bromide of potassium, and water applied to dressings. Of his 308 patients treated in this fashion, only eight (2.6\%) died [49]. Bromine was used widely thereafter to treat gas gangrene, although surgeons were never sure if it was effective [104, 116]. Carbolic acid and sodium hypochlorite also were used to treat established gangrene, but not as prophylaxis [96].

The Spanish-American War was the first major American military encounter since the introduction of Lister's antiseptic technique (1867) and the acceptance of the germ theory of disease, as observed by Robert Koch (18431910) in 1882. Mortality rates decreased with the use of antiseptic dressings in the field and antiseptic/aseptic surgical techniques in hospitals, although sterile technique had not developed to the point that gloves and masks were used $[34,36]$. Surgeons began to associate wound shock with sepsis and administered a saline solution subcutaneously or rectally to hydrate their patients [59]. These innovations almost halved the mortality rates (compared with the Civil War) to $7.4 \%$ of the 1320 patients treated for gunshot wounds, with only 29 cases treated by amputation [22].

Trench warfare during the First World War had several consequences. Soldiers were entrenched in farm fields fertilized with manure, which was rich with anaerobic 
organisms to infect wounds. Static warfare allowed for fixed lines of communication, which with motorized ambulances reduced evacuation time [47]. Machine guns and high-explosive shells caused massive wounds and extensive soft tissue damage. The practice of débridement and delayed primary closure was adopted by US surgeons during the war and all but eliminated the need for amputation as a prophylaxis against infection. It also allowed surgeons to experiment with other surgical techniques, such as leaving bone fragments in place in patients with compound long-bone fractures [31].

In December 1915, French surgeon Alexis Carrel (1873-1944) and English chemist Henry Dakin (18801952) perfected a technique of irrigating wounds with antiseptic Dakin's solution (diluted sodium hypochlorite and boric acid) administered through perforated rubber tubing (Figs. 11, 12). Only after the wound had been disinfected thoroughly was closure attempted. Carrel and Dehelly described the successful treatment of various wounds-fresh, phlegmonous, gangrenous, and suppurating - all of which were disinfected and closed within 20 days [24]. Alexander Fleming (1881-1955) noted an initial benefit to the use of topical solutions, such as carbolic acid, perchloride/biniodide of mercury, boric acid, and hydrogen peroxide, but concluded antiseptics had a longer-term negative effect on healing and advised the surgeon to rely "on his skill alone" [44]. Although Dakin's solution fell into disfavor after the war, some contemporary surgeons have called for a reevaluation of its potential usefulness [93].

Fleming also contributed an early description of the bacteriology of combat wounds. He noted the initial watery, odiferous, red-brown drainage and the presence of

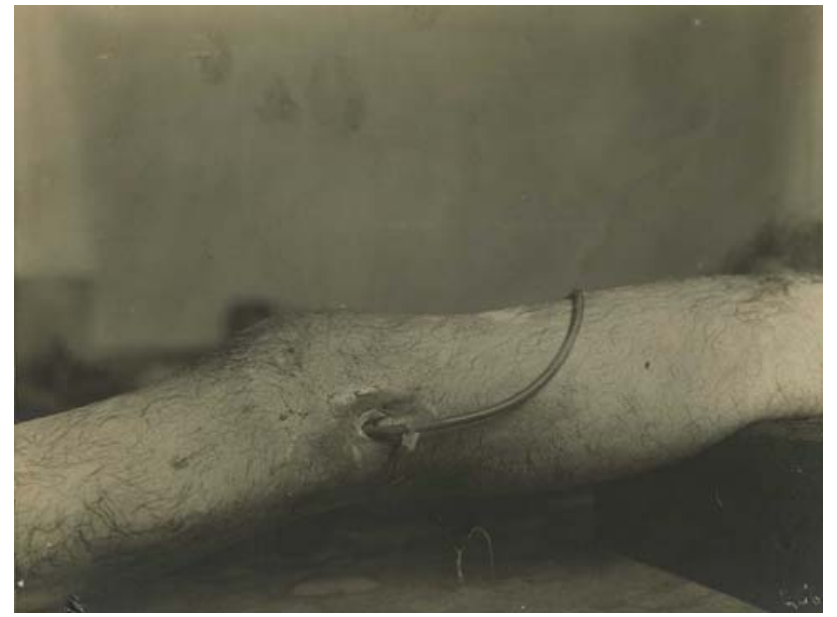

Fig. 11 A tube is inserted in the leg of an American soldier wounded in World War I, providing irrigation of the knee with Dakin's solution. (Courtesy of Otis Historical Archives, National Museum of Health and Medicine, Armed Forces Institute of Pathology, Washington, DC.) anaerobes and streptococci. A week later, in a second phase, the drainage was less bloody and foul-smelling, growing in purulence. Approximately 3 weeks after wounding, in the third phase, streptococci and staphylococci proliferated, as indicated by blood cultures [43].

The equine tetanus antitoxin had been discovered in 1890 and was first distributed on a large scale by British physicians during late 1914. Cases of tetanus decreased from nine per 1000 wounded in September 1914 to 1.4 per 1000 wounded by December 1914 [46]. By the end of World War II, the toxin and its administration were improved to a point that of more than 2.7 million hospital admissions for patients with wounds, only a dozen cases of tetanus were reported [88].

Dissatisfaction with the cumbersome Carrel-Dakin treatment led to its abandonment. During the Spanish Civil War, Josep Trueta (1897-1977) used a closed plaster method to treat 1073 patients with open fractures, with only six deaths and four subsequent amputations. The wounded area was cleaned thoroughly and débrided. The open wound was wrapped in gauze; the fracture was reduced and then immobilized with plaster [137, 138]. More than 20,000 patients were treated with this method during the war [10].

In a previous review of military medicine, RM Hardaway, who treated many of the wounded after Pearl Harbor, met with a team sent by the Army Surgeon General after the attack:

They were amazed at the uniformly well-healed wounds and asked how we treated them. We explained that we did a careful débridement, irrigated the wounds, sprinkled in a little sulfa power (which we had in salt shakers); left the wounds open and

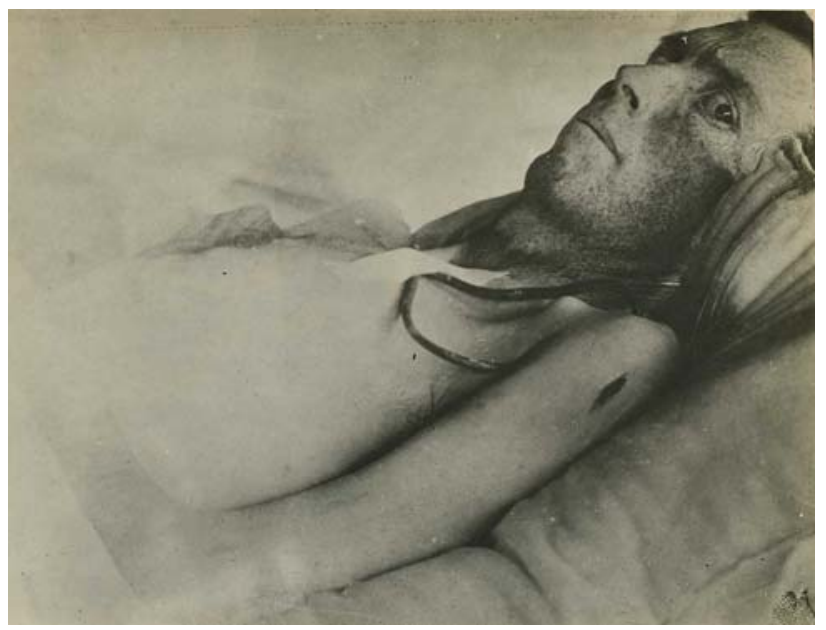

Fig. 12 A US soldier receives treatment in June 1919 via an irrigation tube for Dakin's solution. (Courtesy of Otis Historical Archives, National Museum of Health and Medicine, Armed Forces Institute of Pathology, Washington, DC.) 
performed a delayed primary closure after three days. The immediate reaction was "that sulfanilamide powder is wonderful," missing the point that the débridement and delayed primary closure were the main reason for the clean, uninfected, healed wounds [58].

The Surgeon General recommended sulfa powder be included in all first-aid packets, but instead of being sprinkled, it often was dumped in a lump and thus was ineffective, particularly in wounds that had not been cleaned properly and débrided [58]. By 1944, sulfa powder no longer was issued to soldiers or medics.

Fleming discovered penicillin in 1928 , but it was not until 1939 that an Oxford pathologist, Howard Florey (1898-1968), and his team showed its usefulness in vivo. Penicillin was not used successfully for treatment of a patient until March 1942 [17]. In November 1942, it was first administered to US troops wounded during an assault in Oran, Africa [96]. By then, with British manufacturing dedicated to the production of munitions, development of penicillin for mass production was focused in Peoria, IL, by the US Department of Agriculture, and then later with the US pharmaceutical giants Merck, Squibb, Pfizer, and Abbott. British and American production grew from 21 billion units in 1943 to 6.8 trillion units in 1945 [17]. The first large-scale military use was during the D-Day invasion of Normandy in June 1944. Although penicillin proved effective against Clostridium bacteria, which are responsible for tetanus and gas gangrene, it was considered a safeguard against infection while the surgeons débrided damaged soft tissue. Surgeons usually performed the secondary closure of the wound within 7 days after débridement [57].

In the Korean War, penicillin, usually in combination with streptomycin, remained the most common antibacterial agent used by US military caregivers. The decrease in time from wounding to surgical care thanks to rapid evacuation and MASH units was linked to an impressive reduction in the occurrence of gas gangrene; one study of 4900 wounds revealed a 0.08 incidence of gas gangrene and no mortality attributable to it [74]. Antibiotics were commonly used prophylactically, but at a risk that only became evident in retrospect, as increasingly resistant bacteria were reported from infected war wounds 3 to 5 days after injury [86, 141]. Physicians made a greater effort to identify bacteria and evaluate outcomes of antibiotic strategies. Studies of US wounded showed inadequate débridement to have been the most common cause of infection and prophylactic use of antibiotics was linked to the development of drug-resistant bacteria [141]. A 1951-1952 evaluation of neurosurgical patients in the Tokyo Army Hospital revealed, of 58 isolates from infected wounds, 48 were resistant to penicillin, 49 were resistant to streptomycin, and seven were multidrug resistant [141].

Wound infection data from Vietnam may be misleading. Hardaway, in his classic study of 17,726 patients from 1966 to 1967 , found a postoperative infection rate of $3.9 \%$; however, as he noted, the study only included patients managed in Vietnam and not patients whose infections developed or became apparent later after evacuation [60]. The punji stick, a piece of sharpened bamboo placed in the ground, created lower extremity wounds with a $10 \%$ infection rate, but few fatalities. Seventy percent of the wounded received antibiotics, usually penicillin and streptomycin, and usually intravenously. Eighty percent of wounds underwent débridement. Again, physicians increasingly found patterns of antibiotic resistance. The 1972 study of Tong [136] of 30 Marines injured in combat tracked bacterial flora in wound cultures at injury, after 3 days, and after 5 days, with blood cultures obtained every 8 hours. A mix of gram-positive and gram-negative bacteria most often were found initially, but the pathogens found in Day 5 cultures were mostly gram-negative, most predominantly Pseudomonas aeruginosa. All bacteria from blood cultures were resistant to penicillin and streptomycin [136]. The 1968 study of Kovaric et al. [86] of 112 cultures identified resistant strains of Enterobacter aerogenes, Staphylococcus aureus, Pseudomonas aeruginosa, and Escherichia coli.

During the US engagement in Vietnam, military physicians pioneered the use of pulsatile lavage to reduce bacterial and other contamination and to remove necrotic tissue from crush wounds [80]. Oral surgeons were first to use a modified Teledyne WaterPik ${ }^{\circledR}$ (Teledyne Technologies, Inc, West Los Angeles, CA) to decontaminate facial wounds; orthopaedic surgeons then adapted the instrument and technique to irrigate and débride extremity wounds [52]. Also during the war, a considerable amount of research focused on topical antiseptics for treatment of open wounds and burns. In 1962, a combination of Sulfamylon ${ }^{\circledR}$ (mafenide acetate; UDL Laboratories, Inc, Rockford, IL) and penicillin was used in an animal study to treat massive wounds infected with Clostridium perfringens [94]. The acidosis associated with absorption of the drug led to its later emergence as an ointment (Silvadene ${ }^{\circledR}$; silver sulfadiazine; Aventis Pharmaceuticals Inc, Bridgewater, NJ), a useful antibacterial agent for burn wound treatment. However, topical antibiotics remain controversial and have yet to become a standard of care in military or civilian medicine. Murray et al. [96] reported only approximately $2 \%$ of the wounded in Vietnam were treated with topic antibiotics.

In Iraq and Afghanistan, broad-spectrum antibiotics generally are not administered during early treatment. 
Antibiotic therapy is directed by cultures taken on admission to US military hospitals. In addition to methicillinresistant Staphylococcus aureus, other resistant strains of pathogens have been found in US war wounds [97, 148]. One survey of infections from Combat Support Hospitals in Iraq during 2003 to 2004 showed bacteria most commonly isolated from clinical infections in US troops were coagulase-negative staphylococci, accounting for $34 \%$ of isolates, Staphylococcus aureus (26\%), and streptococcal species (11\%). The 732 cultures obtained from the predominantly Iraqi population included mostly gramnegative bacteria, Klebsiella pneumoniae (13\%), Acinetobacter calcoaceticus-baumannii complex (11\%), and Pseudomonas aeruginosa (10\%). Gram-negative and gram-positive bacteria were resistant to a broad array of antimicrobial agents [148].

\section{Discussion}

It is reasonable in many ways to view the history of military trauma care as a story of constant progress over the long term. Mortality from all wounds decreased dramatically across the 20th century, from $8.5 \%$ among US troops in World War I [36], to 3.3\% in World War II [118], to $2.4 \%$ in Korea [120], and leveling at $2.6 \%$ in Vietnam [58]. Improvements in surgical management stopped the scourge of Clostridium-associated gas gangrene, which had a 5\% incidence and $28 \%$ mortality among US troops in World War I but had fundamentally disappeared by the Korean War [65]. Likewise, the mortality of patients with abdominal wounds declined from $21 \%$ in World War II to $12 \%$ in Korea and $4.5 \%$ in Vietnam [60]. Although the historical trend is reasonably clear, mortality rates can be deceiving, depending, for example, on how those wounded who quickly returned to action were accounted for statistically and aspects that cannot be quantified easily and that have nothing to do with medical advances. Holcomb et al. [69] calculated the death rate from wounds among US troops in Iraq and Afghanistan as 4.8\%, an increase from World War II, Korea, and Vietnam. However, the percentage of those killed in action in Iraq and Afghanistan has actually been lower, $13.8 \%$ compared with $20 \%$ in Vietnam and World War II [69]. This is likely the result of numerous factors, including improved body armor, tactics, the very nature of the mission undertaken by troops, improved front line medical attention, and prompt evacuation. The speed of evacuation increased dramatically from the horse carts of the 19th century and even the motorized transport of World War I; in World War II, the average time from injury to hospitalization was 12 to 15 hours, but by Vietnam it generally was less than 2 hours. As noted, wounded troops in Iraq and Afghanistan can be transported to a combat support hospital in 30 to 90 minutes.

Still, the path toward today's standard of care was not smooth. Misconceptions regarding wound healing persisted in military and civilian medicine until the age of Lister and Pasteur, and the failure to understand wound shock and substitute unsubstantiated theories in place of knowledge resulted in higher mortality rates in both world wars. Worse yet, the lessons regarding shock and delayed primary closure, learned at great human expense in World War I, had to be relearned by Americans in World War II. Also, for most of the history of warfare, at least until World War II, disease usually killed at a higher ratio than battle wounds: nearly 8:1 in the Napoleonic Wars, 4:1 in the Crimean War, 2:1 in the Civil War, 7:1 in the Spanish-American War, and $4: 1$ in World War I [29, 132]. In World War II, the ratio decreased to $0.1: 1$; in Korea and Vietnam, to $0.2: 1$; and in the 1992 Gulf War, to 0.1:1 [132].

The lessons of the history of military emergency medicine are on display in the current operations in Iraq and Afghanistan. The military has a strategy for care, from the training received by an individual soldier, to his squadron's medic, to the provision of a forward medical corps, to immediate transport for emergency surgery, to eventual transport for definitive care and recovery. It is undoubtedly the best-trained, best-equipped, and fastest system of military trauma care in history. However, today's caregivers in the US Army, Navy, Air Force, and Marines also face challenges peculiar to their time and place.

Of crucial importance is the problem of wound infection. As survivorship has increased, even among patients with devastating extremity wounds that would have been fatal in the past, multidrug-resistant pathogens are complicating recovery [78]. A major concern is that past ill-advised use of broad-spectrum antibiotics for empirical treatment of combat wounds is resulting in selection of more resistant pathogens. Additional study in military and civilian settings is needed to refine protocols for antibiotic prophylaxis on the battlefield. Another ongoing challenge is the need to deal with injuries from high-velocity weapons and IEDs, which result in complex, deep wounds, burns, and blunt trauma and represent more than $3 / 4$ of all wounds, according to the Joint Theatre Trauma Registry [108].

Research continues on numerous fronts in this area, much of it under the sponsorship of the federal Orthopaedic Trauma Research Program (OTRP), which has awarded approximately $\$ 14$ million in funding during its first 2 years [112]. Projects currently funded by the OTRP include studies of prevention and treatment of heterotopic ossification; rabbit and rat models of osteomyelitis to evaluate infected extremity wounds; novel therapies for A baumannii; cellular therapy for rapid bone formation; and strategies for treating bone defects involving mesenchymal 
stem cells, antibiotic-impregnated bone cement, and controlled delivery of growth factors $[105,106]$.

Most recently, a team of military and civilian physicians completed a comprehensive review of data and developed published evidence-based guidelines for prevention of infection after combat-related injuries [71]. These include collection and proper use of cultures, administration of antibiotics within 3 hours of injury, a goal of initial evaluation by a surgeon within 6 hours of injury, use of cefazolin in most cases of extremity injury, use of lowpressure lavage, termination of perioperative antibiotics within 24 to 72 hours after surgery, and guidelines for external and internal fixation. Other priorities for research include the optimal timing for débridement and stabilization, complications that may arise from lengthy air transport, such as hypoxia and anatomic trapped gas that expands at higher altitudes $[9,134]$, management of segmental bone defects, and multidisciplinary guidelines for treatment of amputees [111].

The experiences of war-time trauma caregivers have had an undeniable impact on civilian practices, with lessons learned in evacuation, wound management, emergency surgery, infection control, and blood banking. Just the same, the capability of combat medical care has always reflected the technology of its time as, for example, wounded were transported by horse-drawn carriages, then trucks, trains, ships, planes, and helicopters. Although war-time physicians experimented with techniques and protocols that eventually contributed greatly to civilian practice, in today's environment of vast federal funding for health research, programs such as the OTRP bring civilian and military physicians together to seek solutions. Throughout modern warfare, medical care has been reorganized to fit the exigencies of the time and the needs of the wounded. Although the tools and skills available today are more advanced than those possessed by Larrey, Letterman, von Esmarch, and their contemporaries, the mission remains the same.

Acknowledgments We thank Adrianne Noe, PhD, and the staff of the National Museum of Health and Medicine, Armed Forces Institute of Pathology.

\section{Appendix 1}

\section{The Wound-Dresser}

\section{By Walt Whitman (1819-1892)}

From Drum-Taps (1865)

$$
1
$$

An old man bending I come among new faces, Years looking backward resuming in answer to children,
Come tell us old man, as from young men and maidens that love me,

(Arous'd and angry, I'd thought to beat the alarum, and urge relentless war,

But soon my fingers fail'd me, my face droop'd and I resign'd myself,

To sit by the wounded and soothe them, or silently watch the dead;)

Years hence of these scenes, of these furious passions, these chances,

Of unsurpass'd heroes, (was one side so brave? the other was equally brave;)

Now be witness again, paint the mightiest armies of earth,

Of those armies so rapid so wondrous what saw you to tell us?

What stays with you latest and deepest? of curious panics,

Of hard-fought engagements or sieges tremendous what deepest remains?

\section{2}

O maidens and young men I love and that love me, What you ask of my days those the strangest and sudden your talking recalls,

Soldier alert I arrive after a long march cover'd with sweat and dust,

In the nick of time I come, plunge in the fight, loudly shout in the rush of successful charge,

Enter the captur'd works-yet lo, like a swift-running river they fade,

Pass and are gone they fade-I dwell not on soldiers' perils or

soldiers' joys,

(Both I remember well-many the hardships, few the joys, yet I was content.)

But in silence, in dreams' projections,

While the world of gain and appearance and mirth goes on,

So soon what is over forgotten, and waves wash the imprints off the sand,

With hinged knees returning I enter the doors, (while for you up there,

Whoever you are, follow without noise and be of strong heart.)

Bearing the bandages, water and sponge,

Straight and swift to my wounded I go,

Where they lie on the ground after the battle brought in,

Where their priceless blood reddens the grass the ground, 
Or to the rows of the hospital tent, or under the roof' $d$ hospital,

To the long rows of cots up and down each side I return,

To each and all one after another I draw near, not one do I miss,

An attendant follows holding a tray, he carries a refuse pail,

Soon to be fill'd with clotted rags and blood, emptied, and fill'd again.

I onward go, I stop,

With hinged knees and steady hand to dress wounds, I am firm with each, the pangs are sharp yet unavoidable,

One turns to me his appealing eyes-poor boy! I never knew you,

Yet I think I could not refuse this moment to die for you, if that

would save you.

3

On, on I go, (open doors of time! open hospital doors!)

The crush'd head I dress, (poor crazed hand tear not the bandage away,)

The neck of the cavalry-man with the bullet through and through examine,

Hard the breathing rattles, quite glazed already the eye, yet life

struggles hard,

(Come sweet death! be persuaded $\mathrm{O}$ beautiful death!

In mercy come quickly.)

From the stump of the arm, the amputated hand,

I undo the clotted lint, remove the slough, wash off the matter and blood,

Back on his pillow the soldier bends with curv'd neck and side falling head,

His eyes are closed, his face is pale, he dares not look on the

bloody stump,

And has not yet look'd on it.

I dress a wound in the side, deep, deep,

But a day or two more, for see the frame all wasted and sinking,

And the yellow-blue countenance see.

I dress the perforated shoulder, the foot with the bullet-wound,

Cleanse the one with a gnawing and putrid gangrene, so sickening, so offensive,
While the attendant stands behind aside me holding the tray and pail.

I am faithful, I do not give out,

The fractur'd thigh, the knee, the wound in the abdomen,

These and more I dress with impassive hand, (yet deep in my breast

a fire, a burning flame.)

\section{4}

Thus in silence in dreams' projections,

Returning, resuming, I thread my way through the hospitals,

The hurt and wounded I pacify with soothing hand, I sit by the restless all the dark night, some are so young,

Some suffer so much, I recall the experience sweet and sad,

(Many a soldier's loving arms about this neck have cross'd and rested,

Many a soldier's kiss dwells on these bearded lips.)

\section{Appendix 2}

Wound management in Homer's Iliad

From the translation by Samuel Butler, 1898

Wounded Eurypylus made answer, "Noble Patroclus, there is no hope left for the Achaeans but they will perish at their ships. All they that were princes among us are lying struck down and wounded at the hands of the Trojans, who are waxing stronger and stronger. But save me and take me to your ship; cut out the arrow from my thigh; wash the black blood from off it with warm water, and lay upon it those gracious herbs which, so they say, have been shown you by Achilles, who was himself shown them by Chiron, most righteous of all the centaurs. For of the physicians Podalirius and Machaon, I hear that the one is lying wounded in his tent and is himself in need of healing, while the other is fighting the Trojans upon the plain."

"Hero Eurypylus," replied the brave son of Menoetius, "how may these things be? What can I do? I am on my way to bear a message to noble Achilles from Nestor of Gerene, bulwark of the Achaeans, but even so I will not be unmindful your distress."

With this he clasped him round the middle and led him into the tent, and a servant, when he saw him, spread bullock-skins on the ground for him to lie on. He laid him at full length and cut out the sharp arrow from his thigh; he 
washed the black blood from the wound with warm water; he then crushed a bitter herb, rubbing it between his hands, and spread it upon the wound; this was a virtuous herb which killed all pain; so the wound presently dried and the blood left off flowing.

\section{References}

1. Aldrete JA, Marron GM, Wright AJ. The first administration of anesthesia in military surgery: on occasion of the MexicanAmerican War. Anesthesiology. 1984;61:585-588.

2. American Society of Health-System Pharmacists. Armed Services Blood Program therapeutic guidelines on antimicrobial prophylaxis in surgery. Am J Health Syst Pharm. 1999;56:18391888.

3. Andersen RC, Frisch HM, Farber GL, Hayda RA. Definitive treatment of combat casualties at military medical centers. $J$ Am Acad Orthop Surg. 2006;14:S24-S31.

4. Anderson R. An automatic method for treatment of fractures of the tibia and the fibula. J Bone Joint Surg Am. 1934;58:639-646.

5. Artz CP, Bronwell AW, Sako Y. Preoperative and postoperative care of battle casualties. Available at: http://history.amedd.army. mil/booksdocs/korea/recad1/frameindex.html. Accessed Sept. 12, 2008.

6. Bagg MR, Covey DC, Powell ET 4th. Levels of medical care in the global war on terrorism. J Am Acad Orthop Surg. 2006;14:S7-S9.

7. Bagwell CE. Ambroise Pare and the renaissance of surgery. Surg Gynecol Obstet. 1981;152:350-354.

8. Ballard A, Brown PW, Burkhalter WE, Eversmann WW, Feagin JA, Mayfield GW, Omer GE Jr. Orthopedic surgery in Vietnam. Available at: http://history.amedd.army.mil/books docs/vietnam/OrthoVietnam/frameindex.html. Accessed September 11, 2008.

9. Beninati W, Meyer MT, Carter TE. The critical care air transport program. Crit Care Med. 2008;36:S370-S376.

10. Better OS. Josep Trueta (1897-1977): military surgeon and pioneer investigator of acute renal failure. Am J Nephrol. 1999;19:343-345.

11. Blagg CR. Triage: Napoleon to the present day. J Nephrol. 2004; 17:629-632.

12. Blaisdell FW. Medical advances during the Civil War. Arch Surg. 1988;123:1045-1050.

13. Blaisdell FW. Civil War vascular injuries. World J Surg. 2005;29:S21-S24

14. Boe GP, Chinh TV. The military blood programs in Vietnam. Mil Med. 1972;137:109-112.

15. Bollet AJ. Civil War Medicine Challenges and Triumphs. Tucson, AZ: Galen Press Ltd; 2002.

16. Brav EA, Jeffress VH. Fractures of the femoral shaft; a clinical comparison of treatment by traction suspension and intramedullary nailing. Am J Surg. 1952;84:16-25.

17. Brown K. The history of penicillin from discovery to the drive to production. Pharm Hist (Lond). 2004;34:37-43.

18. Brown PW. Recollections of Sterling Bunnell. J Hand Surg [Br]. 1989;14:355-356.

19. Brown PW. War wounds of the hand revisited. J Hand Surg [Am]. 1995;20:S61-S67.

20. Bunnell S. Surgery of the Hand. 1st Ed. Philadelphia, PA: JB Lippincott; 1944.

21. Bunnell S. Hand Surgery. Washington, DC: Office of the Surgeon General, Department of the Army; 1955.
22. Burkhalter WE. Orthopedic Surgery in Vietnam. Washington, DC: Office of the Surgeon General and Center of Military History; 1994.

23. Campion DS, Lynch LJ, Rector FC Jr, Carter N, Shires GT. Effect of hemorrhagic shock on transmembrane potential. Surgery. 1969;66:1051-1059.

24. Carrel A, Dehelly G. The Treatment of Infected Wounds. New York, NY: Paul B. Hoeber; 1917.

25. Carter PR. The embryogenesis of the specialty of hand surgery: a story of three great Americans-a politician, a general, and a duck hunter: The 2002 Richard J. Smith memorial lecture. J Hand Surg [Am]. 2003;28:185-198.

26. Christensen NE. Technique, errors and safeguards in modern Kuntscher nailing. Clin Orthop Relat Res. 1976;115:182-188.

27. Chung KK, Perkins RM, Oliver JD 3rd. Renal replacement therapy in support of combat operations. Crit Care Med. 2008;36:S365-S369.

28. Churchill ED. The surgical management of the wounded in the Mediterranean theater at the time of the fall of Rome [Foreword by Brig. Gen'l Fred W. Rankin, M.C.]. Ann Surg. 1944;120:268-283.

29. Cirillo VJ. Fever and reform: the typhoid epidemic in the Spanish-American War. J Hist Med Allied Sci. 2000;55:363397.

30. Cirillo VJ. The Spanish-American War and military radiology. AJR Am J Roentgenol. 2000;174:1233-1239.

31. Cleveland M. Surgery in World War II Series: Orthopedic Surgery in the European Theater of Operations. Available at: http://history.amedd.army.mil/booksdocs/wwii/orthoeuropn/. Accessed September 9, 2008.

32. Cleveland M, Grove JA. Delayed primary closure of wounds with compound fractures. J Bone Joint Surg Am. 1945;27;446452.

33. Connor H. The use of chloroform by British Army surgeons during the Crimean War. Med Hist. 1998;42:161-193.

34. Cozen LN. Military orthopedic surgery. Clin Orthop Relat Res. 1985;200:50-53.

35. Cunningham JN Jr, Shires GT, Wagner Y. Cellular transport defects in hemorrhagic shock. Surgery. 1971;70:215-222.

36. Depage A. General considerations as to the treatment of war wounds. Ann Surg. 1919;69:575-588.

37. Dougherty PJ. Wartime amputations. Mil Med. 1993;158:755763.

38. Dougherty PJ, Carter PR, Seligson D, Benson DR, Purvis JM. Orthopaedic surgery advances resulting from World War II. J Bone Joint Surg Am. 2004;86:176-181.

39. Driscoll RS. New York Chapter History of Military Medicine Award. U.S. Army medical helicopters in the Korean War. Mil Med. 2001;166:290-296.

40. Duncan LC. Medical Men In The American Revolution 17751783. Available at: http://history.amedd.army.mil/booksdocs/ rev/MedMen/MedMenTitle.html. Accessed September. 11, 2008.

41. Ellis H. A History of Surgery. London, England: Greenwich Medical Media Ltd; 2001.

42. Esmarch F. Historical article. On artificial bloodlessness during operations. 1873. J Hand Surg [Br]. 2006;31:390-396.

43. Fleming A. On the bacteriology of septic wounds. Lancet. 1915;2:638-643.

44. Fleming A. The action of chemical and physiological antiseptics in a septic wound. Brit J Surg. 1919;7:99-129.

45. Freeman FR. Microbes and Minie Balls. Cranbury, NJ: Associated University Press; 1993.

46. Furste W. A golden opportunity. J Trauma. 1998;44:1110-1112.

47. Gajewski D, Granville R. The United States armed forces amputee patient care program. J Am Acad Orthop Surg. 2006;14:S183-S187. 
48. Gill CJ, Gill GC. Nightingale in Scutari: her legacy reexamined. Clin Infect Dis. 2005;40:1799-1805.

49. Goldsmith M. A Report on Hospital Gangrene, Erysipelas and Pyaemia. As Observed in the Departments of the Ohio and the Cumberland, with Cases Appended. Louisville, KY: Bradley \& Gilbert; 1863.

50. Gordon RC, Charles R. Drew: surgeon, scientist, and educator. J Invest Surg. 2005;18:223-225.

51. Griffith JD. Some effects of bullets. Proc Assoc Mil Surg U S. 1897;7:505-520.

52. Gross A, Cutright DE, Larson WJ, Bhaskar SN, Posey WR, Mulcahy DM. The effect of antiseptic agents and pulsating jet lavage on contaminated wounds. Mil Med. 1972;137:145-147.

53. Gross SD. A Manual of Military Surgery. Philadelphia, PA: JB Lippincott \& Co; 1861.

54. Haeger H. The Illustrated History of Surgery. London, England: Harold Starke; 1989.

55. Hagy M. "Keeping up with the Joneses"-the story of Sir Robert Jones and Sir Reginald Watson-Jones. Iowa Orthop J. 2004;24: 133-137.

56. Hamilton FH. A Practical Treatise on Military Surgery. New York, NY: Balleire Bros; 1861.

57. Hampton OP. Orthopedic Surgery in the Mediterranean Theater of Operations. Washington, DC: Office of the Surgeon General; 1957.

58. Hardaway RM. 200 years of military surgery. Injury. 1999;30: 387-397.

59. Hardaway RM. Wound shock: a history of its study and treatment by military surgeons. Mil Med. 2004;169:265-269.

60. Hardaway RM 3rd. Viet Nam wound analysis. J Trauma. 1978;18:635-643.

61. Hau T. The surgical practice of Dominique Jean Larrey. Surg Gynecol Obstet. 1982;154:89-94.

62. Hawk A. An ambulating hospital: or, how the hospital train transformed Army medicine. Civil War History. 2002;48:197219.

63. Hayda R, Harris RM, Bass CD. Blast injury research: modeling injury effects of landmines, bullets, and bombs. Clin Orthop Relat Res. 2004;422:97-108.

64. Hayda RA, Mazurek MT, Powell Iv ET, Richardson MW, Frisch HM, Andersen RC, Ficke JR. From Iraq back to Iraq: modern combat orthopaedic care. Instr Course Lect. 2008;57:87-99.

65. Heisterkamp C 3rd, Vernick J, Simmons RL, Motsumoto T. Topical antibiotics in war wounds: a re-evaluation. Mil Med. 1969;134:13-18.

66. Helling TS, Daon E. In Flanders fields: the Great War, Antoine Depage, and the resurgence of debridement. Ann Surg. 1998;228:173-181.

67. Helling TS, McNabney WK. The role of amputation in the management of battlefield casualties: a history of two millennia. J Trauma. 2000;49:930-939.

68. Hess JR, Thomas MJ. Blood use in war and disaster: lessons from the past century. Transfusion. 2003;43:1622-1633.

69. Holcomb JB, Stansbury LG, Champion HR, Wade C, Bellamy RF. Understanding combat casualty care statistics. J Trauma. 2006;60:397-401.

70. Homer. The Iliad. Lombardo S, trans. Indianapolis, IN: Hackett Publishing Co; 1997.

71. Hospenthal DR, Murray CK, Andersen RC, Blice JP, Calhoun JH, Cancio LC, Chung KK, Conger NG, Crouch HK, D'Avignon LC, Dunne JR, Ficke JR, Hale RG, Hayes DK, Hirsch EF, Hsu JR, Jenkins DH, Keeling JJ, Martin RR, Moores LE, Petersen K, Saffle JR, Solomkin JS, Tasker SA, Valadka AB, Wiesen AR, Wortmann GW, Holcomb JB. Guidelines for the prevention of infection after combat-related injuries. J Trauma. 2008;64:S211-S220.
72. Houghton IT. Some observations on early military anaesthesia. Anaesth Intensive Care. 2006;34(suppl 1):6-15.

73. Howard JM. Battle casualties in Korea: Studies of the Surgical Research Team. Vol III. The Battle Wound: Clinical Experiences. Washington, DC: Army Medical Service Graduate School; 1955.

74. Howard JM, Inui FK. Clostridial myositis; gas gangrene; observations of battle casualties in Korea. Surgery. 1954;36: $1115-1118$.

75. Hunter J. A Treatise on the Blood, Inflammation and Gunshot Wounds. London, England: John Richardson; 1794.

76. Hutchinson G. Words to the wise: poison arrows. BMJ. 1997;314:7082.

77. Iserson KV, Moskop JC. Triage in medicine, part I: concept, history, and types. Ann Emerg Med. 2007;49:275-281.

78. Johnson EN, Burns TC, Hayda RA, Hospenthal DR, Murray CK. Infectious complications of open type III tibial fractures among combat casualties. Clin Infect Dis. 2007;45:409-415.

79. Johnson PC. Guy de Chauliac and the grand surgery. Surg Gynecol Obstet. 1989;169:172-176.

80. Keblish DJ, DeMaio M. Early pulsatile lavage for the decontamination of combat wounds: historical review and point proposal. Mil Med. 1998;163:844-846.

81. Keller TM. A roentgen centennial legacy: the first use of the X-ray by the U.S. military in the Spanish-American War. Mil Med. 1997;162:551-554.

82. Kendrick DB. Blood Program in World War II. Washington, DC: Office of the Surgeon General; 1964.

83. Kiel F. Development of a blood program in Vietnam. Mil Med. 1966;131:1469-1482.

84. Kirk NT. The development of amputation. Bull Med Libr Assoc. 1944;32:132-163.

85. Kirk NT. Amputations 1943. Clin Orthop Relat Res. 1989;243: $3-16$.

86. Kovaric JJ, Matsumoto T, Dobek AS, Hamit HF. Bacterial flora of one hundred and twelve combat wounds. Mil Med. 1968; 133:622-624.

87. Kuz JE. The ABJS Presidential Lecture, June 2004: Our orthopaedic heritage: the American Civil War. Clin Orthop Relat Res. 2004;429:306-315.

88. Long AP. Tetanus in the U.S. Army during World War II. Bull US Army Med Dept. 1947:371-385.

89. Lucas CE. The renal response to acute injury and sepsis. Surg Clin North Am. 1976;56:953-975.

90. Macleod GHB. Notes On The Surgery Of The War In The Crimea, With Remarks On The Treatment Of Gunshot Wounds. London, England: John Churchill; 1858.

91. Magee R. Amputation through the ages: the oldest major surgical operation. Aust N Z J Surg. 1998;68:675-678.

92. Mavroforou A, Koutsias S, Fafoulakis F, Balogiannis I, Stamatiou G, Giannoukas AD. The evolution of lower limb amputation through the ages: historical note. Int Angiol. 2007;26:385-389.

93. McDonnell KJ, Sculco TP. Dakin's solution revisited. Am J Orthop. 1997;26:471-473.

94. Mendelson JA. Topical therapy as an expedient treatment of massive open wounds: experimental study. Surgery. 1960;48: 1035-1047.

95. Metcalfe NH. The influence of the military on civilian uncertainty about modern anaesthesia between its origins in 1846 and the end of the Crimean War in 1856. Anaesthesia. 2005;60:594-601.

96. Murray CK, Hinkle MK, Yun HC. History of infections associated with combat-related injuries. J Trauma. 2008;64(3 suppl):S221-S231.

97. Murray CK, Roop SA, Hospenthal DR, Dooley DP, Wenner K, Hammock J, Taufen N, Gourdine E. Bacteriology of war wounds at the time of injury. Mil Med. 2006;171:826-829. 
98. Nakhgevany KB, Rhoads JE Jr. Ankle-level amputation. Surgery. 1984;95:549-552.

99. Neel S. Medical Support of the U.S. Army in Vietnam, 1965-1970. Available at: http://history.amedd.army.mil/default_ index2.html. Accessed March 5, 2008.

100. Nessen SC, Lounsbury DE, Hetz SP, eds. War Surgery in Afghanistan and Iraq: A Series of Cases, 2003-2007. Washington, DC: Borden Institute; 2008.

101. Newmeyer WL 3rd. Sterling Bunnell, MD: the founding father. J Hand Surg [Am]. 2003;28:161-164.

102. Notes on Care of Battle Casualties: Washington, DC: U.S. War Department; March 1945.

103. Ortiz JM. The revolutionary flying ambulance of Napoleon's surgeon. US Army Medical Department Journal. 1998(OctoberDecember):17-25.

104. Otis GA, Huntington DL. The medical and surgical history of the War of the Rebellion. Part III, Vol. II. Surgical History. Washington, DC: Government Printing Office; 1883.

105. Orthopaedic Trauma Research Program 2006 Funded Proposals. Fort Sam Houston, TX: U.S. Army Institute of Surgical Research; Fall 2006.

106. Orthopaedic Trauma Research Program 2007 Funded Proposals. Fort Sam Houston, TX: U.S. Army Institute of Surgical Research; Fall 2007.

107. Owens BD, Kragh JF Jr, Macaitis J, Svoboda SJ, Wenke JC. Characterization of extremity wounds in Operation Iraqi Freedom and Operation Enduring Freedom. J Orthop Trauma. 2007;21:254-257.

108. Owens BD, Kragh JF Jr, Wenke JC, Macaitis J, Wade CE, Holcomb JB. Combat wounds in operation Iraqi Freedom and operation Enduring Freedom. J Trauma. 2008;64:295-299.

109. Peterson LT. The army amputation program. J Bone Joint Surg Am. 1944;26:635-638.

110. Pikoulis EA, Petropoulos JC, Tsigris C, Pikoulis N, Leppaniemi AK, Pavlakis E, Gavrielatou E, Burris D, Bastounis E, Rich NM. Trauma management in ancient Greece: value of surgical principles through the years. World J Surg. 2004;28:425-430.

111. Pollak AN, Calhoun JH. Extremity war injuries: state of the art and future directions. Prioritized future research objectives. J Am Acad Orthop Surg. 2006;14:S212-S214.

112. Pollak AN, Calhoun JH. Extremity war injuries: state of the art and future directions. Introduction. J Am Acad Orthop Surg. 2006;14:viii-ix.

113. Porter R. The Greatest Benefit to Mankind. New York, NY: Norton; 1997.

114. Potter BK, Scoville CR. Amputation Is Not Isolated: An overview of the US Army Amputee Patient Care Program and associated amputee injuries. $J$ Am Acad Orthop Surg. 2006;14:S188-S190.

115. Price BA. The influence of military surgeons in the development of vascular surgery. J R Army Med Corps. 1999;145:148-152.

116. Pruitt BA Jr. Combat casualty care and surgical progress. Ann Surg. 2006;243:715-729.

117. Quan RW, Adams ED, Cox MW, Eagleton MJ, Weber MA, Fox CJ, Gillespie DL. The management of trauma venous injury: civilian and wartime experiences. Perspect Vasc Surg Endovasc Ther. 2006;18:149-156.

118. Rankin FW. Mission accomplished: the task ahead. Ann Surg. 1949;130:289-309.

119. Rasmussen TE, Clouse WD, Jenkins DH, Peck MA, Eliason JL, Smith DL. Echelons of care and the management of wartime vascular injury: a report from the 332nd EMDG/Air Force Theater Hospital, Balad Air Base, Iraq. Perspect Vasc Surg Endovasc Ther. 2006;18:91-99.

120. Reister FA. Battle casualties and medical statistics: U.S. Army experience in the Korea War. Available at: http://history.amedd.army.mil/booksdocs/korea/reister/default. htm. Accessed March 4, 2008.

121. Rich NM. Vascular trauma in Vietnam. J Cardiovasc Surg (Torino). 1970;11:368-377.

122. Rich NM, Rhee P. An historical tour of vascular injury management: from its inception to the new millennium. Surg Clin North Am. 2001;81:1199-1215.

123. Rutkow IM. Amputation vs nonamputation: a Civil War surgical dilemma. Arch Surg. 1999;134:1284.

124. Rutkow IM. Bleeding Blue and Gray. New York, NY: Random House; 2005.

125. Sachs M, Bojunga J, Encke A. Historical evolution of limb amputation. World J Surg. 1999;23:1088-1093.

126. Schreiber MA, Tieu B. Hemostasis in Operation Iraqi Freedom III. Surgery. 2007;142:S61-S66.

127. Schwechter EM, Swan KG. Raoul Hoffmann and his external fixator. J Bone Joint Surg Am. 2007;89:672-678.

128. Scott R. Care of the battle casualty in advance of the aid station. Available at: http://history.amedd.army.mil/booksdocs/korea/ recad1/frameindex.html. Accessed September 12, 2008.

129. Shaar CM, Kreuz FP, Jones DT. End results of treatment of fresh fractures by the use of the Stader apparatus. J Bone Joint Surg Am. 1944;26:471-474.

130. Sisk TD. External fixation: historic review, advantages, disadvantages, complications, and indications. Clin Orthop Relat Res. 1983;180:15-22.

131. Skandalakis PN, Lainas P, Zoras O, Skandalakis JE, Mirilas P. "To afford the wounded speedy assistance": Dominique Jean Larrey and Napoleon. World J Surg. 2006;30:1392-1399.

132. Smallman-Raynor MR, Cliff AD. Impact of infectious diseases on war. Infect Dis Clin North Am. 2004;18:341-368.

133. Sorokina TS. Russian nursing in the Crimean war. $J R$ Coll Physicians Lond. 1995;29:57-63.

134. Teichman PG, Donchin Y, Kot RJ. International aeromedical evacuation. N Engl J Med. 2007;356:262-270.

135. Teschan PE. Acute renal failure during the Korean War. Ren Fail. 1992;14:237-239.

136. Tong MJ. Septic complications of war wounds. Jama. 1972;219:1044-1047.

137. Trueta J. Reflections on the past and present treatment of war wounds and fractures. Mil Med. 1976;141:255-258.

138. Trueta J. The classic: The treatment of war fractures by the closed method. J. Trueta, M.D. Clin Orthop Relat Res. 1981;156:8-15.

139. U.S. Army Medical Department Medical Science Publication No. 4. Recent Advances In Medicine And Surgery. Vol 19. Washington, DC: U. S. Army Medical Service Graduate School; 1954.

140. van Rens TJ. The history of treatment using plaster of Paris. Acta Orthop Belg. 1987;53:34-39.

141. Wannamaker GT, Pulaski EJ. Pyogenic neurosurgical infections in Korean battle casualties. J Neurosurg. 1958;15:512-518.

142. Weller S. Internal fixation of fractures by intramedullary nailing: introduction, historical review and present status. Injury. 1993;24(suppl 3):S1-S6.

143. Whelton A, Donadiq JV Jr. Post-traumatic acute renal failure in Vietnam: a comparison with the Korean war experience. Johns Hopkins Med J. 1969;124:95-105.

144. Whitman W. Complete Prose Works. New York, NY: Appleton \& Co; 1910.

145. Wilber MC, Willett LV Jr, Buono F. Combat amputees. Clin Orthop Relat Res. 1970;68:10-13.

146. Winslow GR. Triage and Justice. Berkeley, CA: University of California Press; 1982.

147. Woodward EB, Clouse WD, Eliason JL, Peck MA, Bowser AN, Cox MW, Jones WT, Rasmussen TE. Penetrating 
femoropopliteal injury during modern warfare: experience of the Balad Vascular Registry. J Vasc Surg. 2008;47:1259-1264; discussion 1264-1255.

148. Yun HC, Murray CK, Roop SA, Hospenthal DR, Gourdine E, Dooley DP. Bacteria recovered from patients admitted to a deployed U.S. military hospital in Baghdad, Iraq. Mil Med. 2006;171:821-825.

149. Zetterstrom R. The Nobel Prize for the discovery of human blood groups: start of the prevention of haemolytic disease of the newborn. Acta Paediatr. 2007;96:1707-1709. 